PNL-6930

UC-11,41

$6 c$

\title{
Ground-Water Monitoring \\ Compliance Plan for the Hanford Site Solid Waste Landfill
}

R. M. Fruland

October 1986

Prepared for the U.S. Department of Energy under Contract DE-AC06-76RLO 1830

Pacific Northwest Laboratory

Operated for the U.S. Department of Energy

by Battelle Memorial Institute 


\title{
DISCLAIMER
}

This program was prepared as an account of work sponsored by an agency of the United States Government. Neither the United States Government nor any agency thereof, nor Battelle Memorial Institute, nor any or their employees, makes any warranty, expressed or implied, or assumes any legal liability or responsibility for the accuracy, completeness, or usefulness of any information, apparatus, product, or process disclosed, or represents that its use would not infringe privately owned rights. Reference herein to any specific commercial product, process, or service by trade name, trademark, manufacturer, or otherwise, does not necessarily constitute or imply its endorsement, recommendation, or favoring by the United States Government of any agency thereof, or Battelle Memorial Institute. The views and opinions of authors expressed herein do not necessarily state or reflect those of the United States Government or any agency thereof.

\author{
PACIFIC NORTHWEST LABORATORY \\ operated by \\ BATTELLE MEMORIAL INSTITUTE \\ for the \\ UNITED STATES DEPARTMENT OF ENERGY \\ under Contract DE-ACOG-76RLO 1830
}

Printed in the United States of America

Available to DOE and DOE contractors from the

Office of Scientific and Technical Information, P.O. Box 62, Oak Ridge, TN 37831;

prices available from (615) 576-8401. FTS 626-8401.

Available to the public from the National Technical Information Service,

U.S. Department of Commerce, 5285 Port Royal Rd., Springfield, VA 22161.

NTIS Price Codes, Microfiche A01

\begin{tabular}{|c|c|}
\hline \multicolumn{2}{|c|}{ Printed Copy } \\
\hline & Price \\
\hline Pages & Codes \\
\hline$\overline{007-025}$ & $\mathrm{~A} 02$ \\
\hline $026-050$ & $\mathrm{~A} 03$ \\
\hline $051-075$ & $\mathrm{AO4}$ \\
\hline $076-100$ & $\mathrm{~A} 05$ \\
\hline $101-125$ & A06 \\
\hline $126-150$ & $\mathrm{~A} 07$ \\
\hline $151-175$ & $\mathrm{~A} 08$ \\
\hline $176-200$ & $\mathrm{~A} 09$ \\
\hline $201-225$ & A 10 \\
\hline $226-250$ & A11 \\
\hline 251.275 & $\mathrm{~A} 12$ \\
\hline $276-300$ & A13 \\
\hline
\end{tabular}


PNL -6930

UC $-11,41$

GROUND-WATER MONITORING COMPLIANCE PLAN

FOR THE HANFORD SITE SOLID WASTE LANDFILL

R. M. Fruland

October 1986

Prepared for

the U.S. Department of Energy

under Contract DE-AC06-76RLO 1830

Pacific Northwest Laboratory

Richland, Washington 99352 


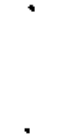




\section{DISCLAIMER}

The procedures and preliminary interpretations in this document reflect condiditons in 1986 and are thus subject to change as a result of ongoing technical audits and reviews. 



\section{SUMMARY}

Washington state regulations required that solid waste landfill facilities have ground-water monitoring programs in place by May 27, 1987. This document describes the well locations, installation, characterization studies and sampling and analysis plan to be followed in implementing the ground-water monitoring program at the Hanford Site Solid Waste Landfill (SWL). It is based on Washington Administrative Code WAC 173-304-490. 



\section{CONTENTS}

INTRODUCTION

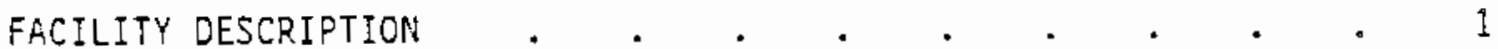

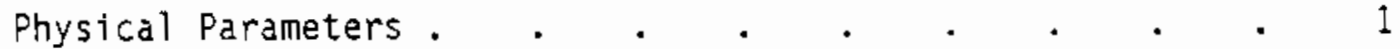

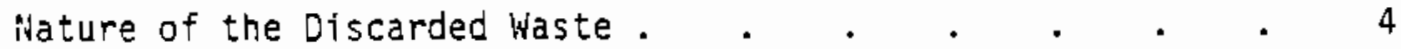

Method of Operation . . . . . . . . . . 4

GEOGRAPHIC SETTING OF THE CENTRAL LANDFILL . . . . . . 5

Geology . . . . . . . . . . . . . 5

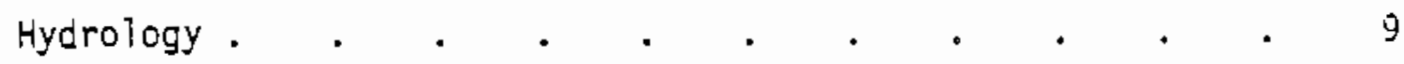

HISTORICAL GROUND-WATER MONITORING DATA . . . . . . . 14

Water Table Data . . . . . . . . . . . . . 14

Chemical Data . . . . . . . . . . . 17

Results from the NROW Landfill Drilling . . . . . : 23

COMPLIANCE PLAN FOR THE SOLID WASTE LANDFILL • • • • • • • • • 25

PLANNEO WELL INSTALLATION . . . . . . . . . . 25

Rationaie. . . . . . . . . . . . . . 25

Completion Depths . . . . . . . . . . . . 27

Well Construction Detalls,$\quad . \quad . \cdot$. . . . 27

Hydrogeologic Testing and Characterization . . . . 30

Vadose Zone Sampling . . . . . . . . . . . . 31

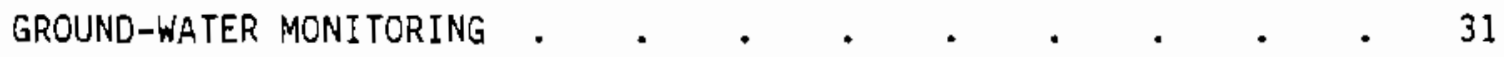

Field Measurements . . . . . . . . . . . . 31

Sampling preparation . . . . . . . . . . . 32

Sample Collection . . . . . . . . . . . 32

Sample Preservation . . . . . . . . . . 33

Chain-of-Custody . . . . . . . . . . . 33

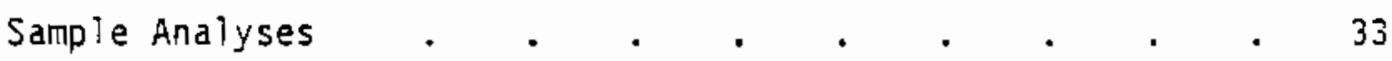

Quality Assurance . . . . . . . . . . 34

Quality Control . . . . . . . . . . . 35

Data Handling and Verification . . . . . . . . 36

Data Evaluation . . . . . . . . . . 38 


\section{FIGURES}

1 Location of the Solid Waste Landfill on the Hanford Site, Washington State

2 Site Plan for the Hanford Site Solid Waste Landfill . . . 3

3 Geological Setting of the Hanford Solid Waste Landfill . . . 6

4 Aerial View of Kanford's Central Landfill, Looking Northeast

Across the Pasco Basin . . . . . . . . . . 7

5 Aerial View of the Solid Waste Landfill's Active and Future

Sections, Looking Towards the Southwest . . . . . . . 8

6 Map of the Solid Waste Landfill Area Showing the Local

Existing Wells from Which Data has been Compiled . . . . 10

7 Regional Cross Section A-A' with Upgradient and Downgradient

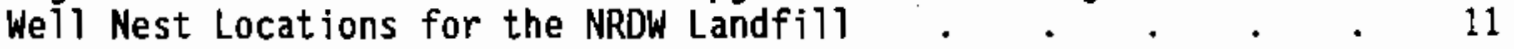

8 Regional Cross Section B-B' Illustrating Units and Water

Table Beneath the Solid Waste Landfill . . . . . . 12

9 Water Table Map in the Area of the Solid Waste Landfjll . . 13

I0 Hanford Site Water Table-Map, December 1985 . . . . . . 15

11 Water-Table Elevations Through Time for Well 6-24-33 . . . 17

12 Water-Table Elevations Through Time for Well 6-28-40 . . . 18

13 Cobalt 60 Concentrations for well 6-24-33 . . . . . 18

14 Tritium Concentrations for Weil 6-24-33 . . . . . . . 21

15 Coba\}t 60 Concentrations for Well 6-28-40 . . . . . . 22

16 Nitrate Concentrations for Well o-28-40. . . . . . . . 22

17 Geologic Units at the Solid Waste Landifl . . . . . . . 24

18 Planned Well Installation at the Solid Waste Landfill . . 26

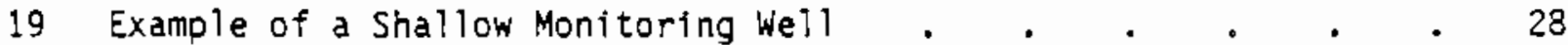




\section{TABLES}

1 Water Table Elevations from Semi-Annual Meesurement between December 1975 ard December 1984 at Five Wells Near the

Solid Waste Landfill $. \quad . \quad . \quad . \quad . \quad . \quad . \quad . \quad 15$

2 Chemical Data for Wells 6-24-33 and 6-28-40 . . . . . 19

3 Standard List of Analyses for the Solid Waste Landfill

Ground-Water Monitoring Effort . . . . . . . . . 34

4 Water Mezsurements and Constituent Analyses Required by State of washington Reguiations WAC 173-304 for Groundwater Monitoring of Solid Waste Landfilis . . . . . . 



\section{INTRODUCTION}

This plan has been written to ensure that U.S. Department of Energy, Richland Operations office (DOE-RL), activities meet requirements set forth in the Washington Administrative Code (WAC) 173-304 concerning solid waste management. Under these regulations, by May 27, 1987, the owner/operator of a solid waste facility must have a ground-water monitoring program capable of determining the ground-water quality of the uppermost aquifer underlying the facility. The monitoring is to be carried out on a quarterly basis. This document contains the ground-water monitoring plan designed to ensure compliance with the monitoring requirements of WAC 173-304 for the Hanford Site Solid Waste Landfil1.

\section{FACILITY DESCRIPTION}

The Solid Waste Landfill is operated by the DOE-RL. The only physical facilities at this landfill are the perimeter fence and a trailer. There is no continuous operational water supply to the Landfill. Drinking water supplies for operating personnel are carried to the site in 5-gal containers. This and the following information have been provided by Rockwell Hanford Operations (Rockwel1).

\section{Physical Parameters}

The Central Landfill, including the Solid Waste Landfill and the Non-Radioactive Dangerous Waste Landfill, is located approximately $16 \mathrm{mi}$ northwest on Route 4 from Spengler Road in Richland (Figure 1). Figure 2 illustrates the site plan for the Central Landfill. The northern section of the facility is allocated for the disposal of non-radioactive dangerous waste (NRDW) materials. This section is being treated as a separate facility, the NROW Landfill, covered by Federal Regulation 40 CFR 265, Subpart F, and state regulation WAC 173-303, and is not considered here. The NRDW Landfill is separated from the present 


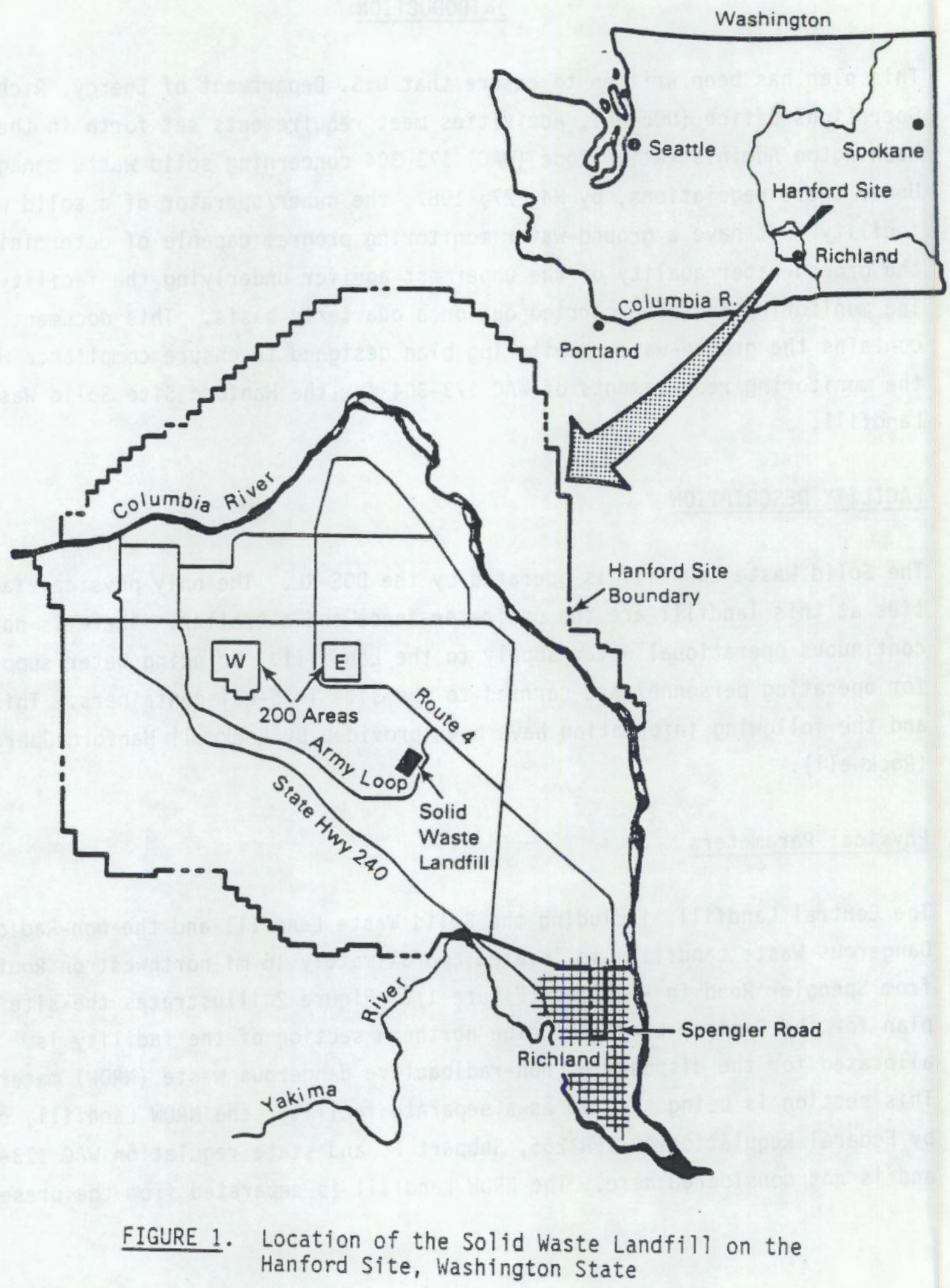



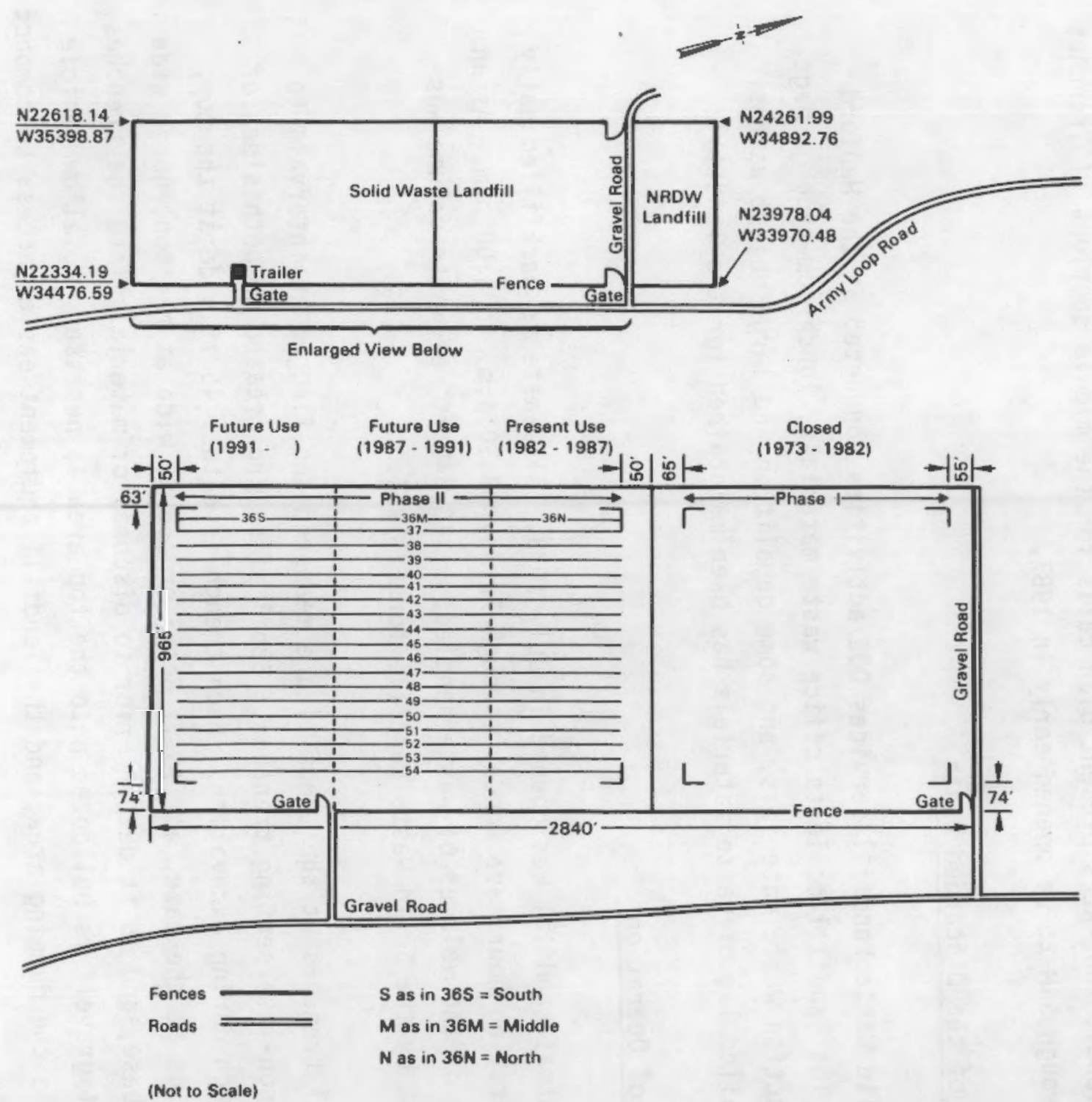

FIGURE 2. Site Plan for the Hanford Site Solid Waste Landfill 
and future Solid Waste Landfill by $1220 \mathrm{ft}$ of a closed section of the Solid Waste Landfill. All trenches in this section (Phase I Trash Trenches) were closed by July, 1982. In Phase II, which opened in July 1982, sixteen trenches have been filled with trash. Some of these are larger diameter trenches than others (see "Method of Operation," below). Trenches $52 \mathrm{~N}$ and $53 \mathrm{~N}$ are currently operational. DOE-RL's present plan calls for the middle sections of Trenches $37 M$ through 54M to be opened early in 1987.

\section{Nature of the Discarded Waste}

The Solid Waste Landfill services DOE activities conducted at the Hanford Site. The Landfill collects office waste materials, lunchroom-type garbage, construction waste materials, and some demolition and large object wastes. No detailed log of waste materials has been maintained for the landfill.

\section{Method of Operation}

The Central Landfill was opened in July 1973. All waste is backfilled daily and operating hours are Monday through Friday, 8:30 a.m. to 3:00 p.m. As an example of the volumes of waste handled, 1,110,548 $\mathrm{ft}^{3}$ of waste volume was accepted by the Solid Waste Landfill for FY 1984.

Disposal trenches at the Landfill are measured and flagged at intervals to ensure non-intersecting trenches. Spoil piles are created on both sides of the trench during excavation. Each trench is either $46 \mathrm{ft}$ wide at the top, $14 \mathrm{ft}$ wide at the base, and $15 \mathrm{ft}$ deep; or $106 \mathrm{ft}$ wide at the top, $65 \mathrm{ft}$ wide at the base, and $15 \mathrm{ft}$ deep. Prior to disposal of materials into the trenches, "ballast gravel" is bulldozed onto the top area as necessary to allow vehicle access to the dumping area, and the landfill equipment easier access to compact the waste. 
GEOGRAPHIC SETTING OF THE CENTRAL LANDFILL

The Hanford Site is located near the center of the Columbia Plateau, in south-central washington state. The site lies within a structural and topographic low known as the Pasco Basin (Figure 3 ). The Pasco Basin is bounded by a series of anticlinal structures: the Saddle Mountains to the north, Umtanum and Yakima Ridges to the west, and the Rattlesnake and Horse Heaven Hills to the south and southwest. A broad regional monocline is the buried structural border on the east. There are a large number of publications on the geology of the Columbia Plateau. The following references, used in preparation of the summary presented here, contain additional references, as well as much greater detail than could be included here: Waters (1969), Baker and Nummedal (1978), Gephardt et al. (1979), Tallman et al. (1979), and Barrash et al. (1983).

\section{Geology}

Within the Pasco Basin is approximately $10,000 \mathrm{ft}$ of dominantly Miocene flood basalts known as the Columbia River Basalts. Above the basalts is the Ringold Formation of late Miocene to Pliocene age, composed of a series of fluvial and lacustrine deposits, divided simply into basal, lower, middle, and upper Ringold units. Interfingered among these deposits are eroded and weathered basalt lenses from the surrounding basalt ridges, referred to as the Ringold Fanglomerate. Above the Upper Ringold is a discontinuous unit called the Early Palouse Soil, or Plio-Pleistocene unit, which is composed mainly of calcareous sand, silt, and eolian deposits. In most areas in the Pasco Basin, the Ringold is overlain by the Hanford Formation of Pleistocene age. It consists of the deposits left by pre-glacial flooding at the end of the last Ice Age (approximately 13,000 to $18,000 \mathrm{yrs}$ ago). These deposits include new materials introduced by the flooding, plus reworking of the Ringold deposits. Eolian deposits of recent origin overlie the Hanford Formation in some areas on the Hanford Site. The sand cover is thin to absent around the landfill. Figures 4 and 5 are photographs of the landfill area, illustrating the surface appearance, aridity, and vegetation in the local vicinity. 


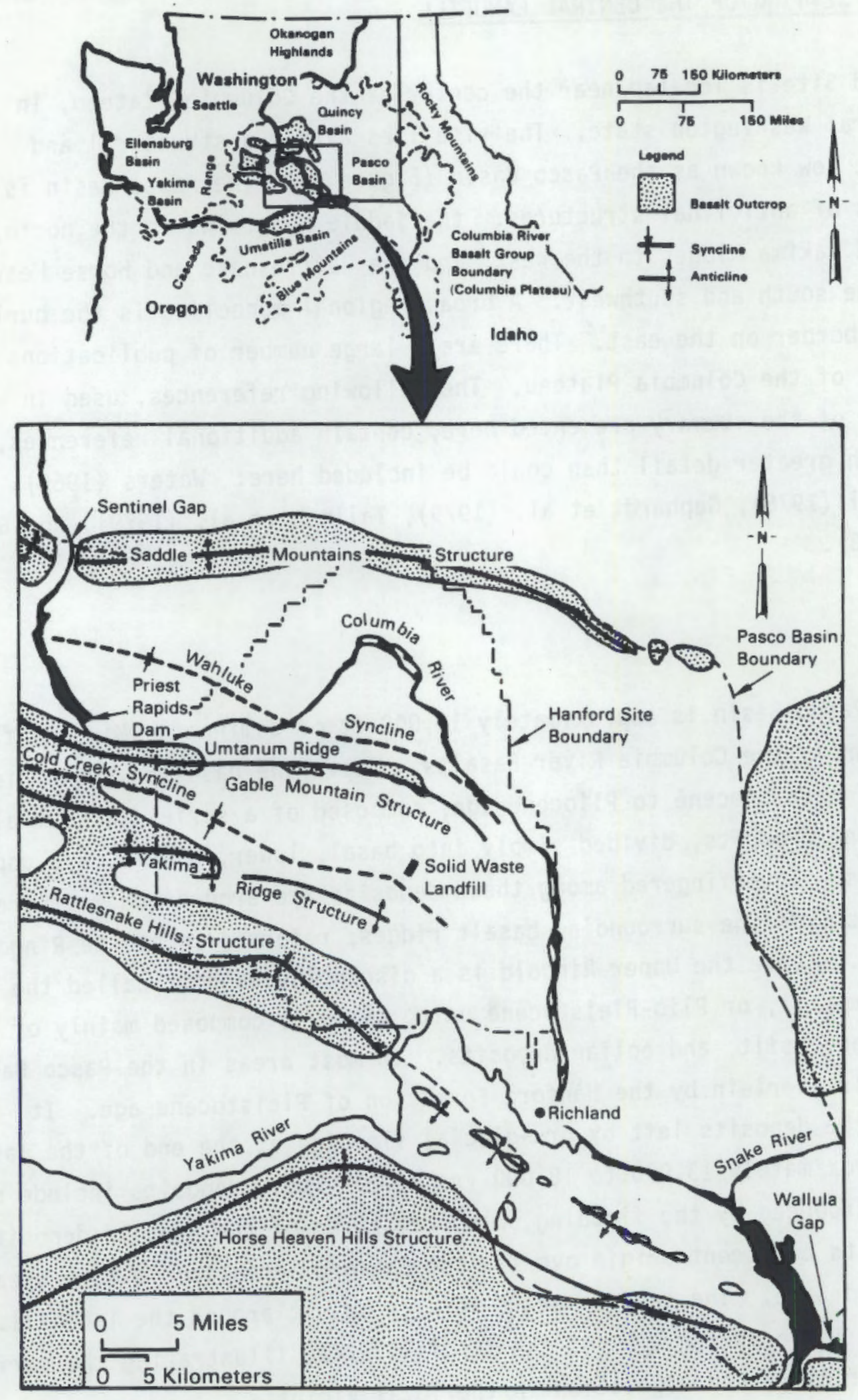

FIGURE 3. Geological Setting of the Hanford Solid Waste Landfill 


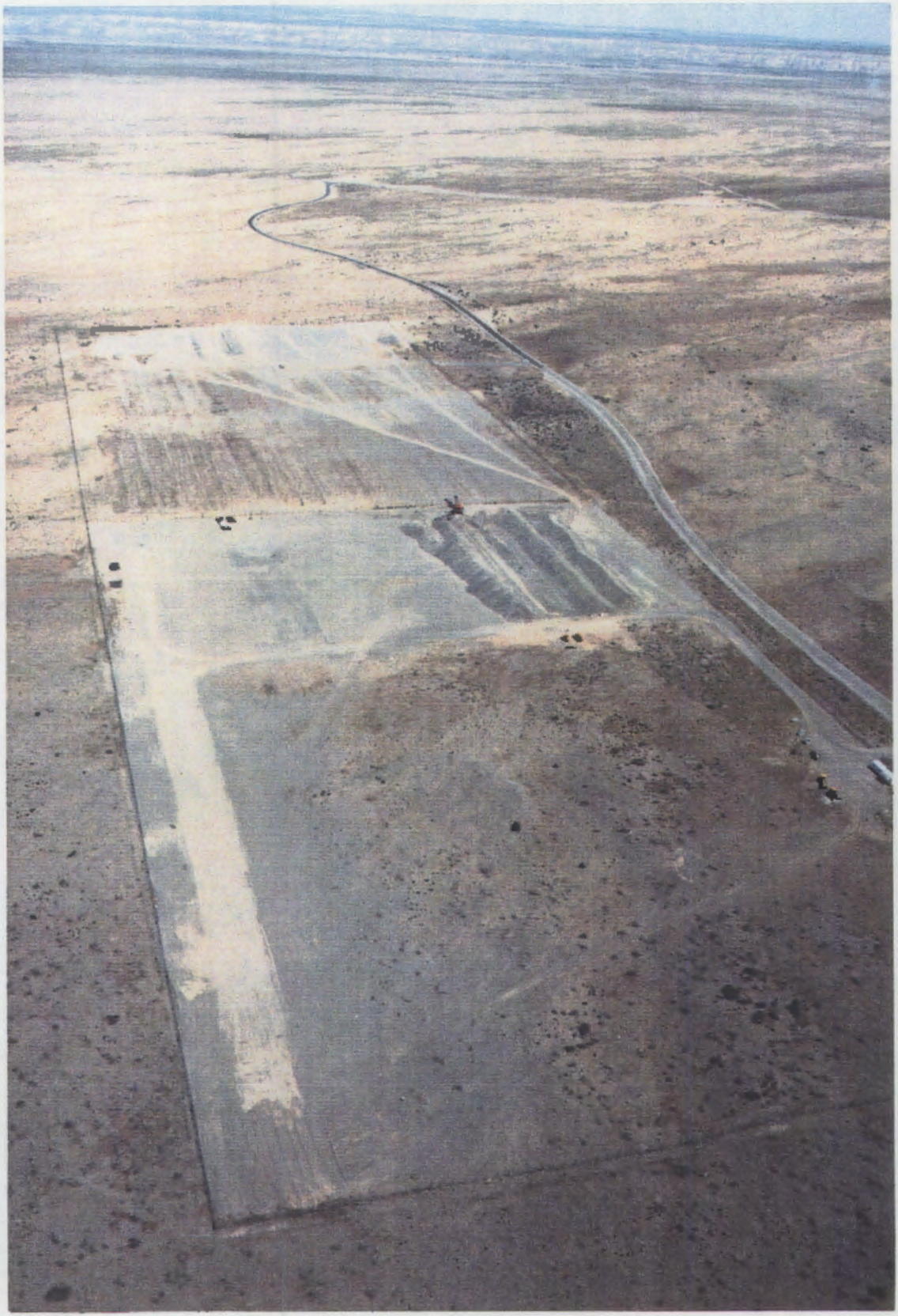

FIGURE 3. Aerial View of Hanford's Solid Waste Landfill and Nonradioactive Dangerous Waste Landfi11, Looking Northeast Across the Pasco Basin. The rectangular outline includes the Solid Waste Landfill (center and foreground); and the Nonradioactive Dangerous Waste Landfill, along the northern edge. Note the active trench in the Solid Waste Landfill in the center of the photograph. The section with the diagonal road across it is the closed Phase I section of the Solid Waste Landfill. 


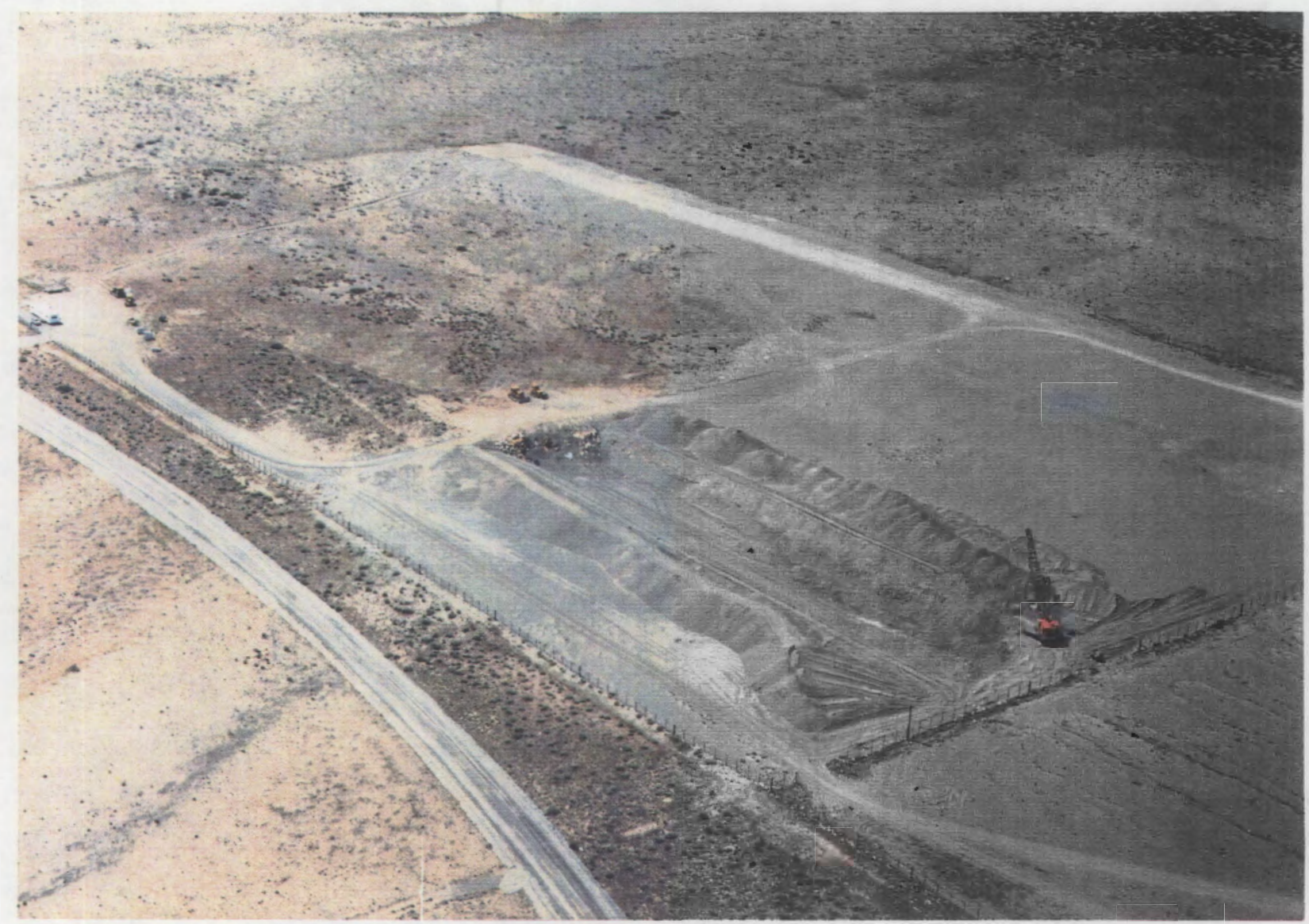

FIGURE 5. Aerial View of the Solid Waste Landfill's Active and Future Sections, Looking Towards the South West. Note the area's aridity and relatively flat topography, evident in both Figure 4 and 5 . 
Figure 6 is a map of the Solid Waste Landfill area showing the local wells from which the cross sections in Figures 7 and 8 were derived. The cross sections indicate the geologic units present under the landfil1, and the depth of the water table. Hanford and Upper Ringold units are present, and the water table is encountered approximately $125 \mathrm{ft}$ from the surface. The Elephant Mountain Member of the Saddle Mountains Basalt Formation is the top unit of the Columbia River Basalts in this part of the Pasco Basin. The landfill is located over a structural low, or syncline, known as the Cold Creek Syncline (see also Figure 3 ).

\section{Hydrology}

One of the largest river systems in North America, the Columbia River and its tributaries, the Snake and the Yakima, passes through the Pasco Basin. The Columbia and Yakima Rivers cut across and border portions of the Hanford Site (Figure 3). Aquifers in the Hanford units discharge to the Columbia River within the Hanford Site boundary. Movement in the aquifers is generally from northwest to southeast. Natural recharge primarily occurs along the western periphery of the Hanford Site where precipitation and runoff infiltrate the water table. Small ephemeral streams draining the western slopes, such as Cold Creek and Dry Creek, lose water to the ground as they spread out on the valley plain. Artificial recharge to the ground water occurs on the Hanford Site from waste water disposal operations. The water table elevation under the Solid Waste Landfill is apparently dominated by the waste water discharge in the 200 Areas, and specifically the cooling water disposal at B-Pond (DOE$R L, 1986)$.

Based on data from present wells near the Solid Waste Landfill, the water table is approximately $125 \mathrm{ft}$ beneath the surface. The unconfined aquifer gradient is very low, on the order of 0.5 to $0.1 \mathrm{ft} / 1000 \mathrm{ft}$. The water table map 111 ustrates that the direction of flow is from the west-northwest to eastsoutheast (Figure 9). Figure 7 shows the regional cross section (1ine $A-A^{\prime}$ in Figure 6 ), including the relative locations and completion depths of the 


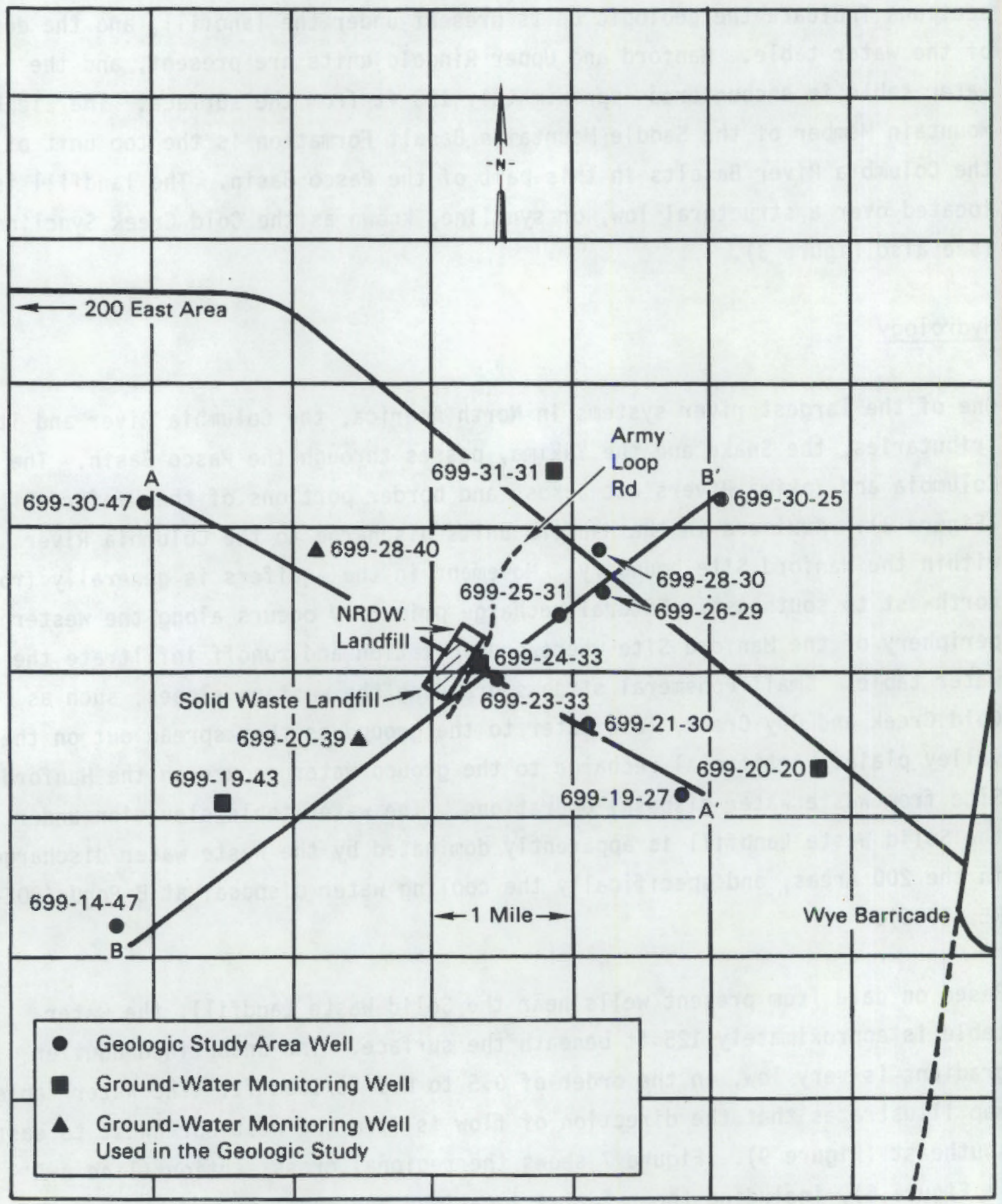

FIGURE 6. Map of the Solid Waste Landfill Area Showing the Local Existing Wells from which Data has been Compiled 


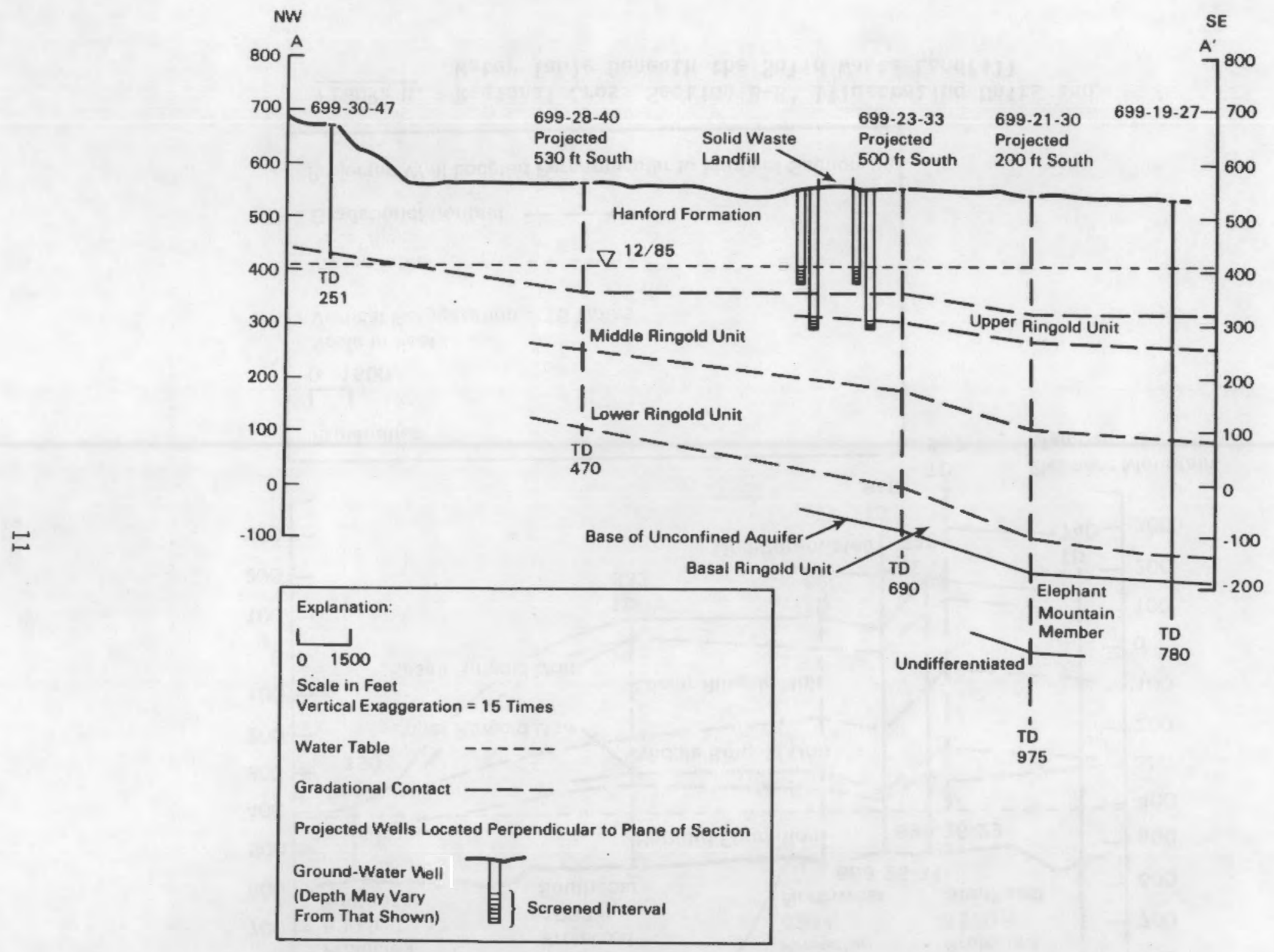

FIGURE 7. Regional Cross Section A-A' with Upgradient and Downgradient Wel1 Nest Locations for the NRDW Landfill 


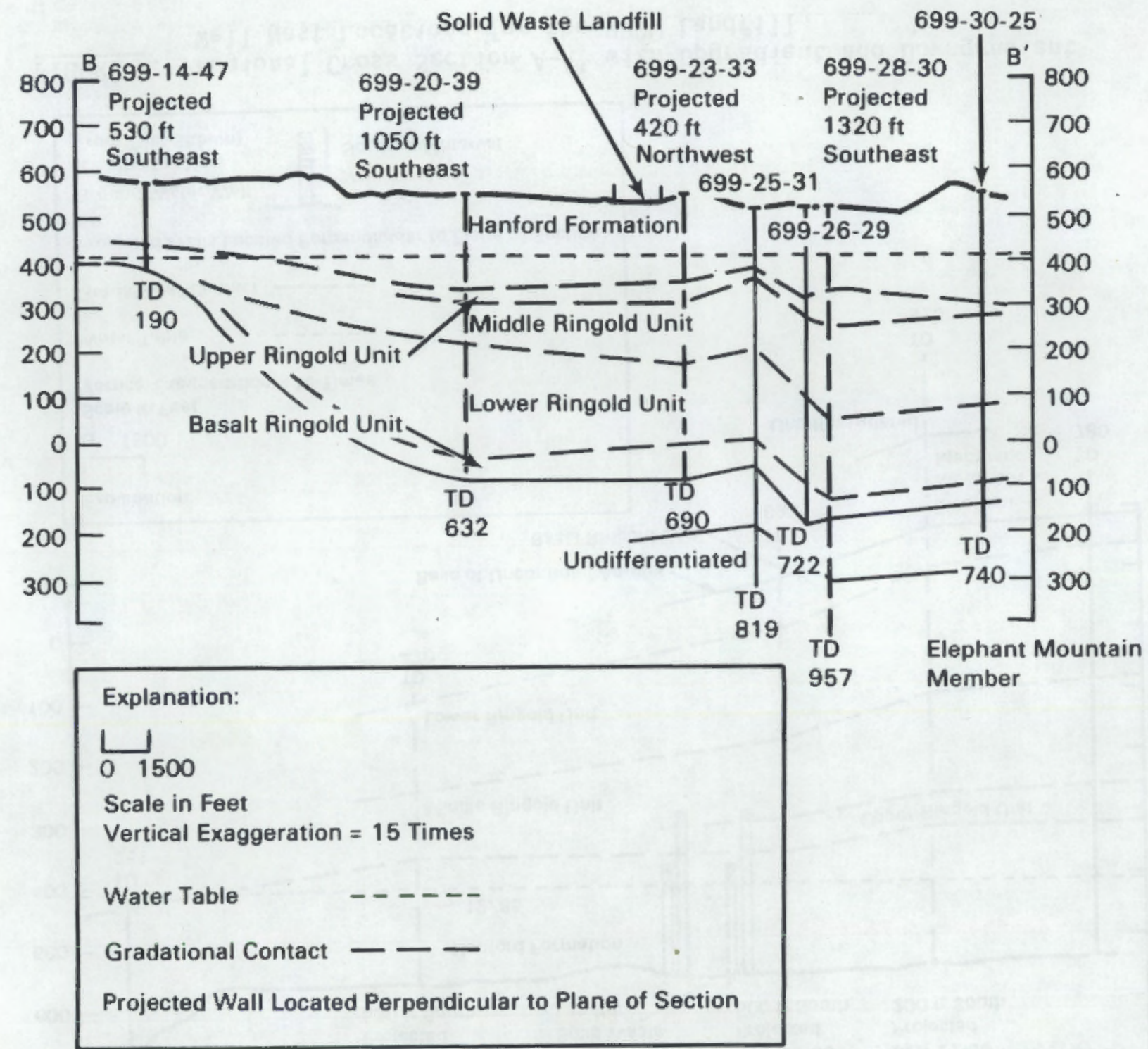

FIGURE 8. Regional Cross Section B-B' Illustrating Units and Water Table Beneath the Solid Waste Landfill 


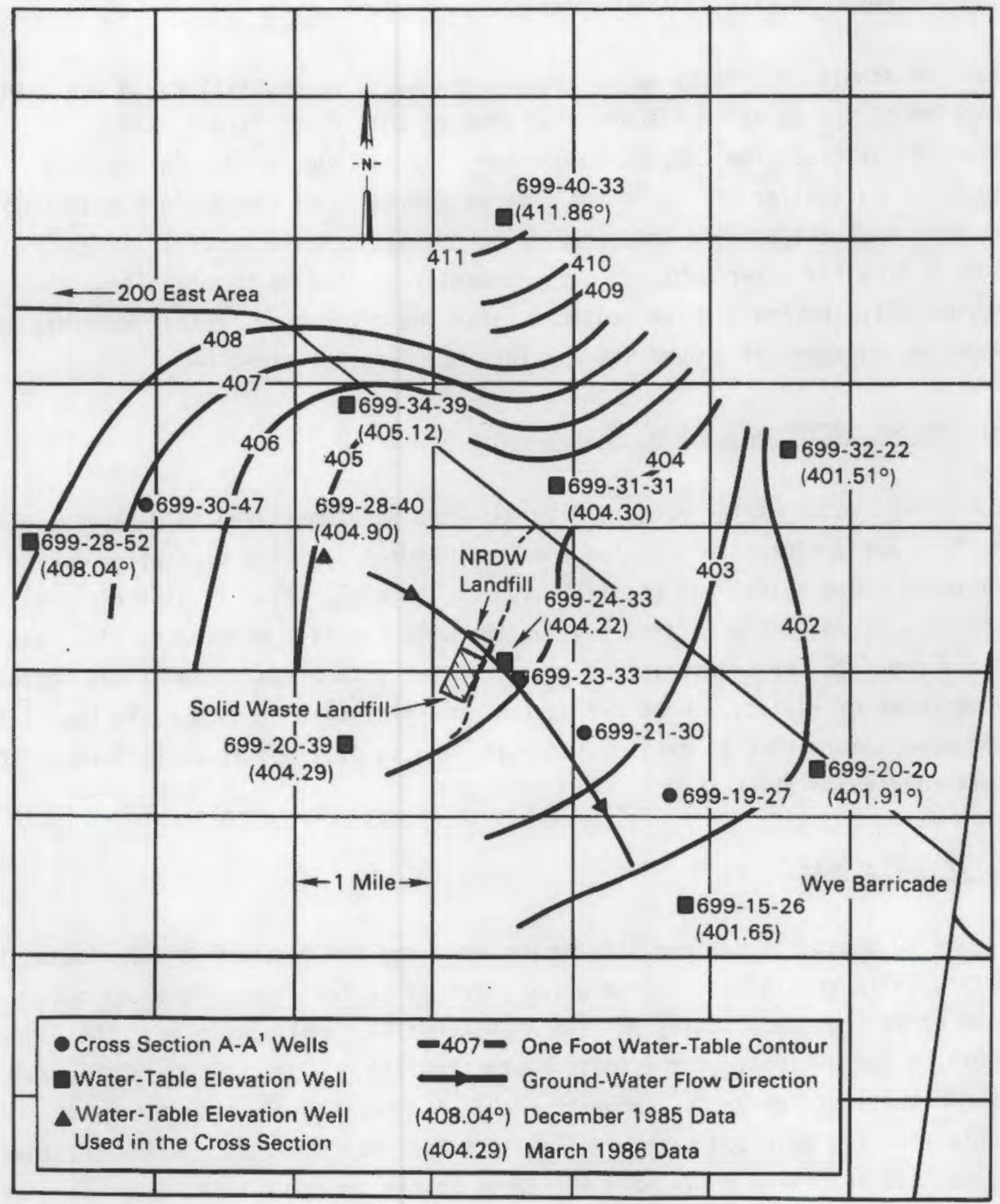

FIGURE 9. Water Table Map in the Area of the Solid Waste Landfill 
well nests presently, being installed near the NRDW Landfill. A total of nine wells will monitor the NRDW site, including two observation wells, used to monitor water table elevations only.

Earlier studies of nearby wells suggest hydraulic conductivities in the upper portion of the unconfined aquifer of greater than 7,000 ft/day, and transmissivities from 200,000 to greater than $300,000 \mathrm{ft}^{2} /$ day (Bierschenk, 1959). The aquifer occurs in the layered sediments of the Hanford and Ringold formations. The aquifer thickness below the Solid Waste Landfill is about $580 \mathrm{ft}$ from the water table to the basement rock (Saddle Mountain Basalt Formation). Layers of fine sediment (silt and clay) form partial barriers to vertical movement of ground water within the Ringold Formation.

\section{HISTORICAL GROUND-WATER MONITORING DATA}

The ground water at the Hanford Site has long been monitored to determine how Hanford activities have affected the local hydrology. The monitoring has included hydrological and chemical studies. A compilation of historical data was made as reference information for the NRDW Landfill compliance plan, and was filed with the Department of Energy (DOE-RL), and the State of Washington Department of Ecology. Considering the proximity of the Solid Waste Landfill, the same information is pertinent for it, and is provided as an attachment to this compliance plan.

\section{Water Table Data}

Figure 10 shows the Hanford Site water table map for December 1985. The monitoring wells are indicated from which water table levels and chemical data were collected specifically for the NRDW Landfill compliance plan. The water table in the vicinity of the Solid Waste Landfill has not changed appreciably within the last few years. However, Table 1 shows the depth to the water table for five selected nearby wells, from 1975 through 1985. All water table elevations for these wells have increased on the order of a few feet over the 


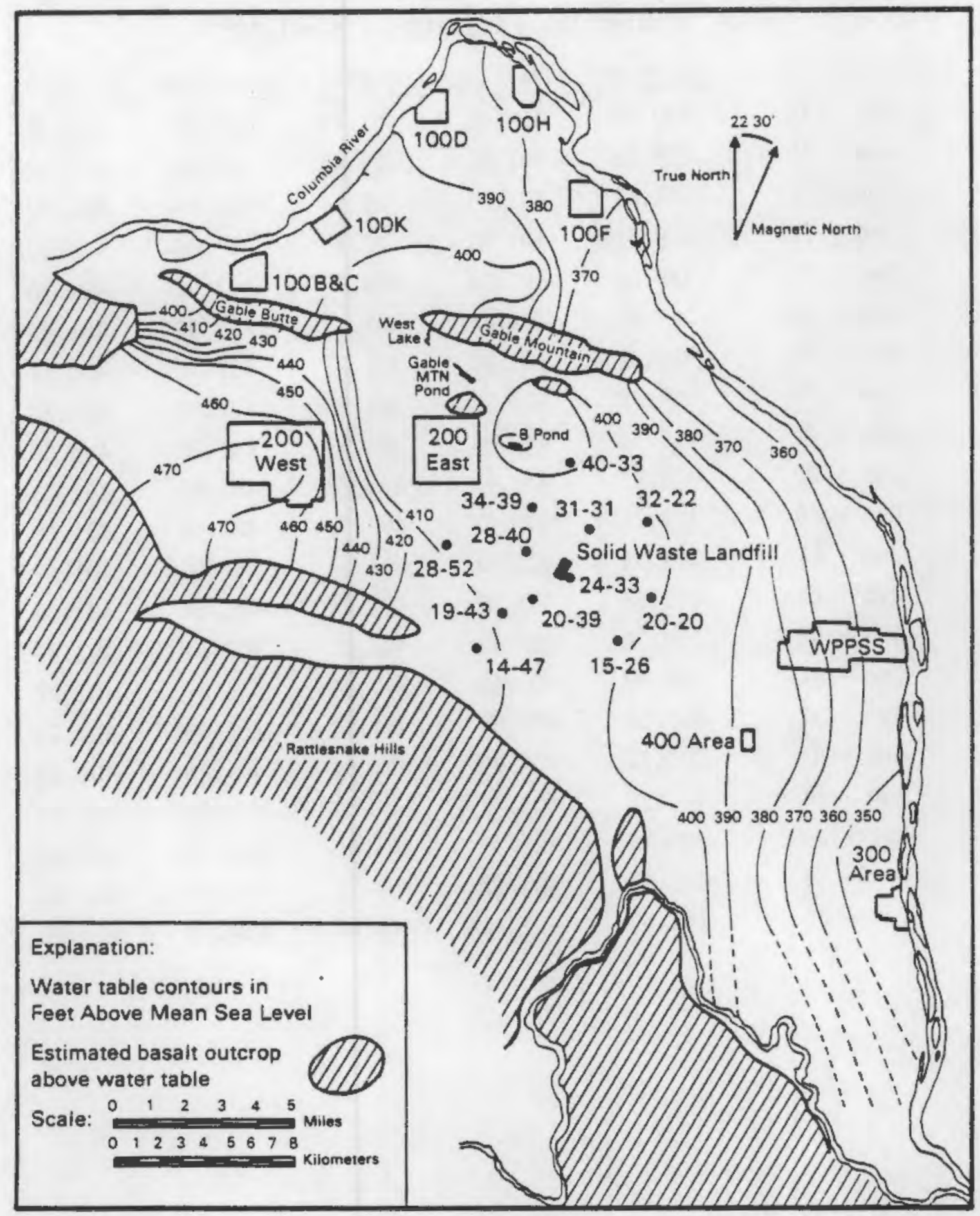

FIGURE 10. Hanford Site Water Table Map, December 1985 
TABLE 1. Water Table Elevations from Semi-Annual Measurements between December 1975 and December 1984 at Five Wells Near the Solid Waste Landfill

$$
\text { Water Table Elevation (ft-ms } 1 \text { ) (a) }
$$

\begin{tabular}{|c|c|c|c|c|c|}
\hline Dec -75 & 399.84 & 402.05 & 401.80 & 402.06 & 401.56 \\
\hline Jun - 76 & 399.76 & 401.81 & 401.48 & 402.04 & 401.46 \\
\hline Dec -76 & 399.69 & 401.74 & 401.44 & 401.94 & 401.42 \\
\hline Jun - 77 & 399.67 & 401.76 & 401.48 & 401.96 & 401.45 \\
\hline Dec -77 & 399.68 & 401.74 & 401.55 & 402.01 & 401.56 \\
\hline Jun - 78 & 399.68 & 401.85 & 401.45 & 401.99 & 401.43 \\
\hline Dec -78 & 399.52 & 401.51 & 401.32 & 401.75 & 401.31 \\
\hline Jun - 79 & 399.48 & 401.58 & 401.23 & 401.80 & 401.22 \\
\hline Dec -79 & 399.44 & 401.68 & 401.33 & 401.78 & 401.30 \\
\hline Jun -80 & 399.45 & 401.48 & 401.22 & 401.67 & 401.23 \\
\hline Dec -80 & 399.45 & 401.43 & 401.27 & 401.82 & 401.28 \\
\hline Jun - 81 & 399.35 & 401.53 & 401.14 & 401.66 & 401.17 \\
\hline Dec - 81 & 399.68 & 401.39 & 401.23 & 401.64 & 401.24 \\
\hline Jun - 82 & 399.32 & 401.40 & 401.07 & 401.51 & 401.39 \\
\hline Dec - 82 & 399.40 & 401.45 & 401.24 & 401.89 & 401.27 \\
\hline Jun - 83 & 399.52 & 401.60 & 401.34 & 401.96 & 401.35 \\
\hline Dec -83 & 399.70 & 401.99 & 401.84 & 401.46 & 401.85 \\
\hline Jun - 84 & 400.16 & 402.75 & 402.50 & 403.28 & 402.53 \\
\hline Dec -84 & 399.83 & 403.29 & 403.02 & 403.78 & 403.09 \\
\hline Jun - 85 & 401.03 & 403.42 & 403.16 & 403.91 & 401.32 \\
\hline Dec -85 & 401.53 & 404.16 & 404.00 & 404.78 & 404.06 \\
\hline
\end{tabular}

$\frac{699-20-20}{399.84} \quad \frac{699-20-39}{402.05} \quad \frac{699-24-33}{401.80} \quad \frac{699-28-40}{402.06} \quad \frac{699-31-31}{401.56}$ 
last 10 yrs. Going back even further in time for two wells (6-24-33 and 6-28-40) that have been monitored since the 1940's and 1950's, respectively, it is obvious that there has been a significant increase in the water table elevation, on the order of $10 \mathrm{ft}$ or more (Figures 11 and 12). Hanford operations release significant amounts of water in the two 200 Areas, creating "mounds" in the water table, which have, and continue to, influence water table levels, and movement in the unconfined aquifer.

\section{Chemical Data}

In addition to monitoring water table levels, flow, and other hydrologic parameters, Hanford wells also have been used to routinely collect samples for chemical analyses for radioisotopes and nitrate. Table 2 presents this chemical data for wells 6-24-33 and 6-28-40 for the years 1980-1985. Because this data is more difficult to scan in tabular form, Figures 13 and 14 present two constituents for we11 6-24-33, and Figures 15 and 16 present two constituents

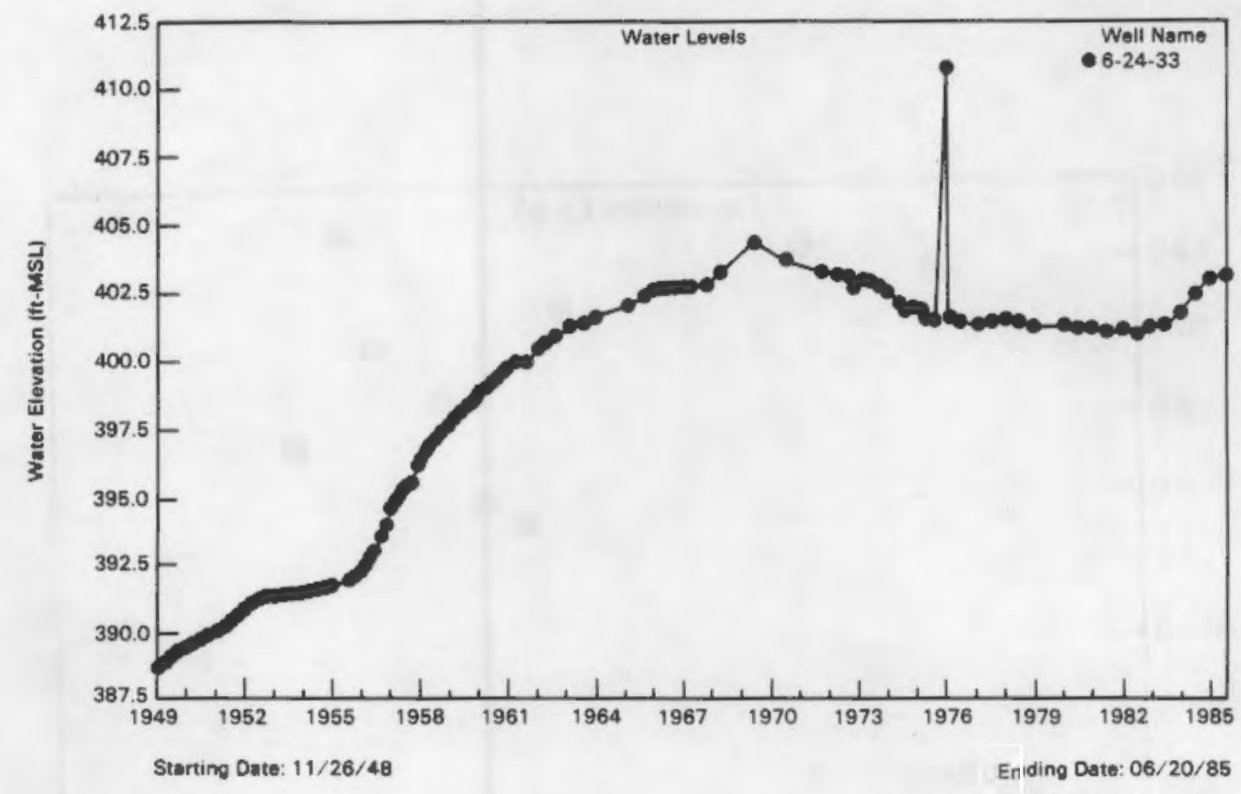

FIGURE 11. Water Table Elevations (Unverified) Through Time for Well 6-24-33 


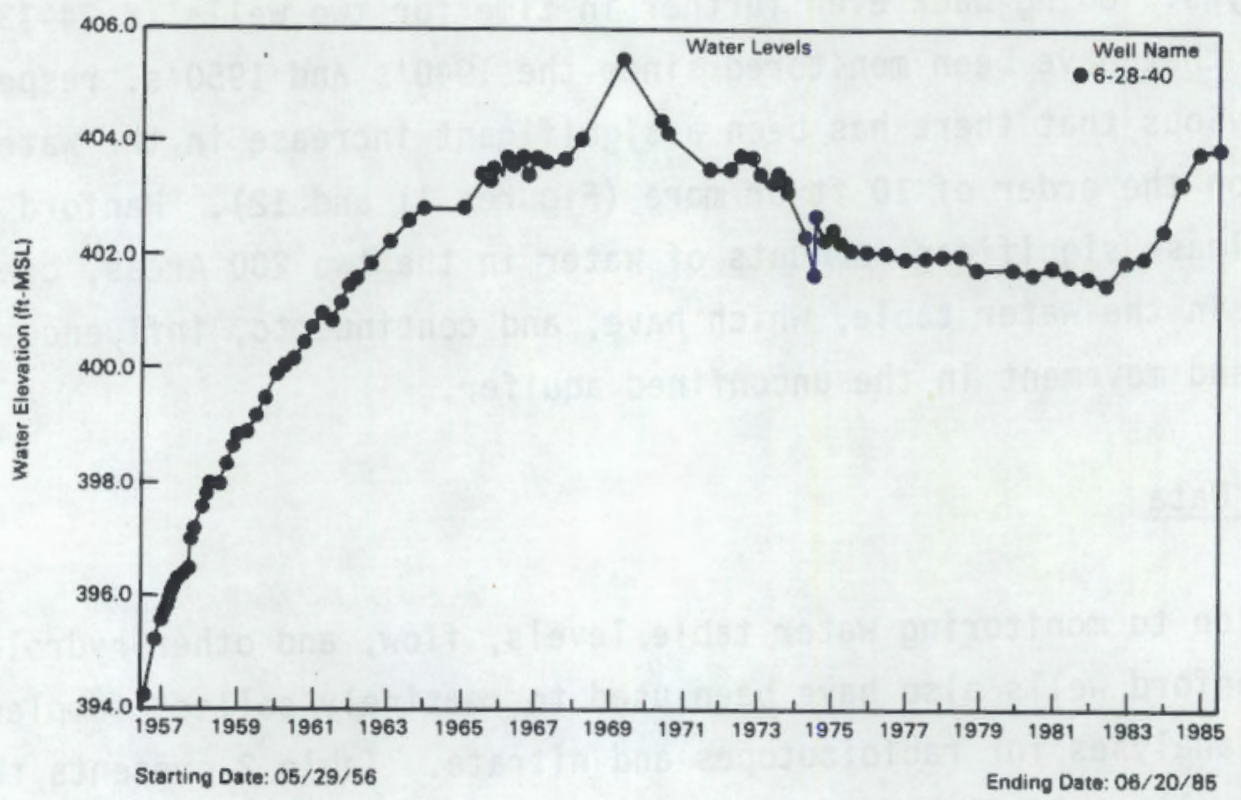

FIGURE 12. Water-Table Elevations (Unverified) Through Time for Well 6-28-40

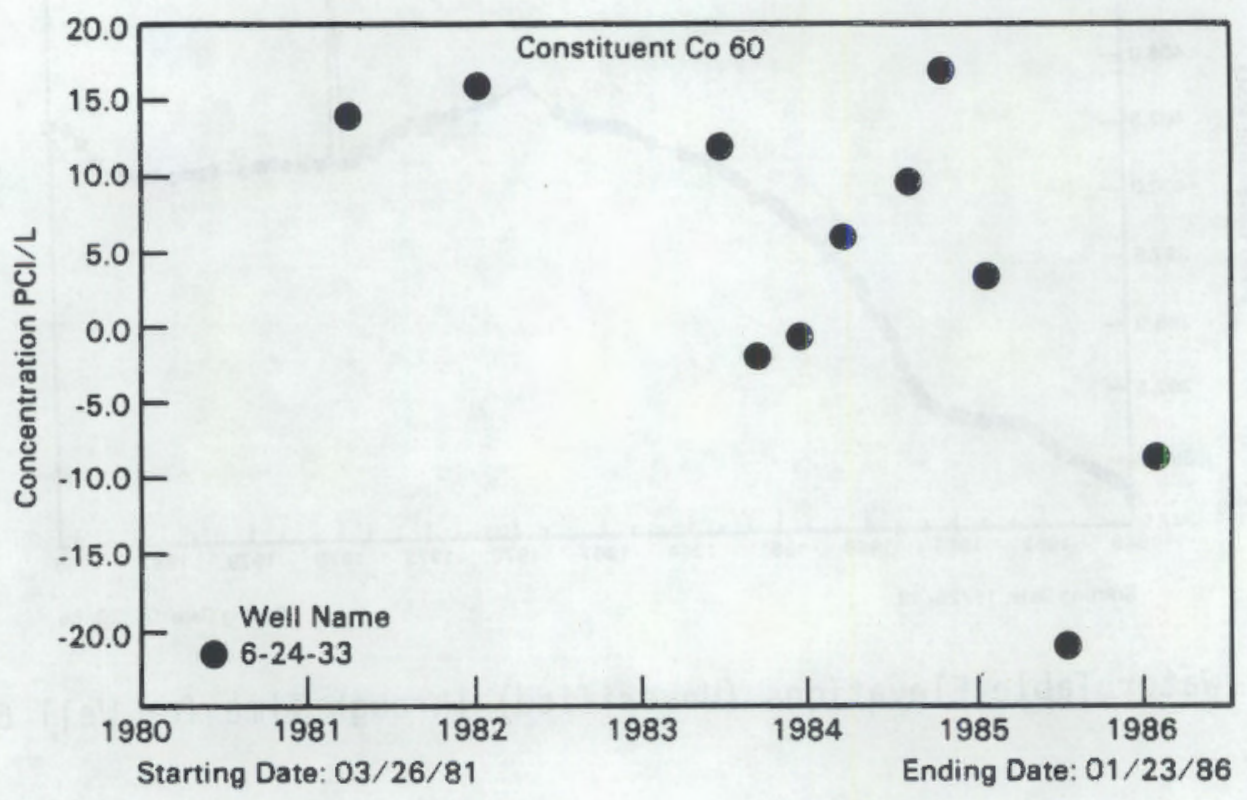

FIGURE 13. Cobalt 60 Concentrations for well 6-24-33 (Unverified) 
TABLE 2. Chemical Data for Wells 6-24-33 and 6-28-40 (Unverified)

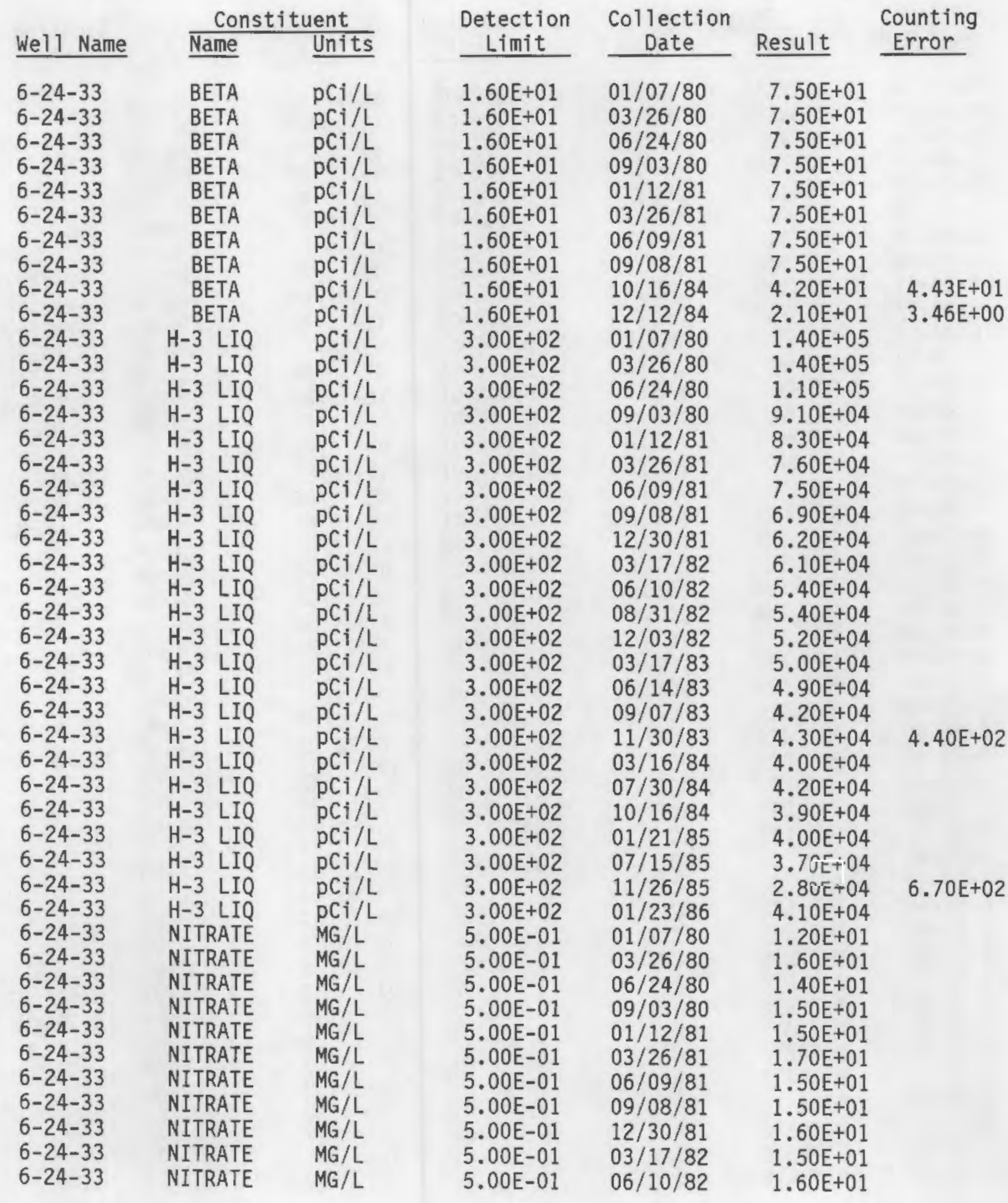


TABLE 2. (Contd)

\begin{tabular}{|c|c|c|c|c|c|c|}
\hline \multirow[b]{2}{*}{ Well Name } & \multicolumn{2}{|c|}{ Constituent } & \multirow{2}{*}{$\begin{array}{c}\text { Detection } \\
\text { Limit } \\
\end{array}$} & \multirow{2}{*}{$\begin{array}{c}\text { Collection } \\
\text { Date } \\
\end{array}$} & \multirow[b]{2}{*}{ Result } & \multirow{2}{*}{$\begin{array}{l}\text { Counting } \\
\text { Error }\end{array}$} \\
\hline & Name & Units & & & & \\
\hline $6-24-33$ & NITRATE & $M G / L$ & $5.00 \mathrm{E}-01$ & $08 / 31 / 82$ & $1.60 \mathrm{E}+01$ & \\
\hline $6-24-33$ & NITRATE & $\mathrm{MG} / \mathrm{L}$ & $5.00 E-01$ & $12 / 03 / 82$ & $1.40 E+01$ & \\
\hline $6-24-33$ & NITRATE & $M G / L$ & $5.00 \mathrm{E}-01$ & $03 / 17 / 83$ & $1.60 E+01$ & \\
\hline $6-24-33$ & NITRATE & $M G / L$ & $5.00 \mathrm{E}-01$ & $09 / 07 / 83$ & $1.50 \mathrm{E}+01$ & \\
\hline $6-24-33$ & NITRATE & $M G / L$ & $5.00 \mathrm{E}-01$ & $11 / 30 / 83$ & $1.60 E+01$ & \\
\hline $6-24-33$ & CO 60 & $\mathrm{pCi} / \mathrm{L}$ & $2.00 \mathrm{E}+01$ & $03 / 26 / 81$ & $1.40 \mathrm{E}+01$ & \\
\hline $6-24-33$ & CO 60 & $\mathrm{pCi} / \mathrm{L}$ & 2. $00 \mathrm{E}+01$ & $12 / 30 / 81$ & $1.60 \mathrm{E}+01$ & \\
\hline $6-24-33$ & CO 60 & $\mathrm{pCi} / \mathrm{L}$ & 2. $00 \mathrm{E}+01$ & $06 / 14 / 83$ & $1.20 \mathrm{E}+01$ & $5.50 E+00$ \\
\hline $6-24-33$ & CO 60 & $\mathrm{pCi} / \mathrm{L}$ & $2.00 \mathrm{E}+01$ & $09 / 07 / 83$ & $-2.10 E+00$ & $4.80 E+00$ \\
\hline $6-24-33$ & CO 60 & $\mathrm{DCi} / \mathrm{L}$ & $2.00 E+01$ & $11 / 30 / 83$ & $-7.40 E-01$ & $3.10 \mathrm{E}+00$ \\
\hline $6-24-33$ & Co 60 & $\mathrm{pCi} / \mathrm{L}$ & 2. $00 \mathrm{E}+01$ & $03 / 16 / 84$ & $6.00 \mathrm{E}+00$ & $3.10 \mathrm{E}+00$ \\
\hline $6-24-33$ & $\cos 60$ & $\mathrm{pCi} / \mathrm{L}$ & $2.00 E+01$ & $07 / 30 / 84$ & $9.70 E+00$ & 3. $30 \mathrm{E}+00$ \\
\hline $6-24-33$ & CO 60 & $\mathrm{pCi} / \mathrm{L}$ & $2.00 E+01$ & $10 / 16 / 84$ & $1.70 E+01$ & $5.70 \mathrm{E}+00$ \\
\hline $6-24-33$ & CO 60 & $\mathrm{pCi} / \mathrm{L}$ & $2.00 E+01$ & $01 / 21 / 85$ & $3.20 \mathrm{E}+00$ & $3.10 \mathrm{E}+00$ \\
\hline $6-24-33$ & CO 60 & $\mathrm{pCi} / \mathrm{L}$ & $2.00 E+01$ & $07 / 15 / 85$ & 2. $10 E+01$ & 3. $30 \mathrm{E}+01$ \\
\hline $6-24-33$ & CO 60 & $\mathrm{pCi} / \mathrm{L}$ & $2.00 E+01$ & $11 / 26 / 85$ & $2.00 E+01$ & $2.50 \mathrm{E}+01$ \\
\hline $6-24-33$ & CO 60 & $\mathrm{pCi} / \mathrm{L}$ & $2.00 E+01$ & $01 / 23 / 86$ & $-8.80 \mathrm{E}+00$ & $6.40 E+00$ \\
\hline $6-28-40$ & BETA & $\mathrm{PCi} / \mathrm{L}$ & $1.60 \mathrm{E}+01$ & $09 / 30 / 84$ & $1.92 \mathrm{E}+01$ & $4.54 \mathrm{E}+01$ \\
\hline $6-28-40$ & $\mathrm{H}-3 \mathrm{LIQ}$ & $\mathrm{pCi} / \mathrm{L}$ & $3.00 E+02$ & $01 / 17 / 80$ & $2.60 \mathrm{E}+04$ & \\
\hline $6-28-40$ & $\mathrm{H}-3$ LIQ & $\mathrm{pCi} / \mathrm{L}$ & $3.00 E+02$ & $03 / 28 / 80$ & $1.00 \mathrm{E}+04$ & \\
\hline $6-28-40$ & $\mathrm{H}-3 \mathrm{LIQ}$ & $\mathrm{pCi} / \mathrm{L}$ & $3.00 E+02$ & $06 / 11 / 80$ & $1.10 \mathrm{E}+04$ & \\
\hline $6-28-40$ & $\mathrm{H}-3 \mathrm{LIQ}$ & $\mathrm{pCi} / \mathrm{L}$ & $3.00 E+02$ & $09 / 04 / 80$ & $2.20 E+04$ & \\
\hline $6-28-40$ & $\mathrm{H}-3 \mathrm{LIQ}$ & $\mathrm{pCi} / \mathrm{L}$ & $3.00 \mathrm{E}+02$ & $03 / 23 / 81$ & 1. $30 \mathrm{E}+04$ & \\
\hline $6-28-40$ & $\mathrm{H}-3$ LIQ & $\mathrm{pCi} / \mathrm{L}$ & $3.00 E+02$ & $06 / 12 / 81$ & $1.50 E+04$ & \\
\hline $6-28-40$ & $\mathrm{H}-3 \mathrm{LIQ}$ & $\mathrm{pCi} / \mathrm{L}$ & $3.00 E+02$ & $09 / 09 / 81$ & $4.40 E+03$ & \\
\hline $6-28-40$ & $\mathrm{H}-3 \mathrm{LIQ}$ & $\mathrm{pCi} / \mathrm{L}$ & $3.00 E+02$ & $01 / 06 / 82$ & $9.30 E+03$ & \\
\hline $6-28-40$ & $\mathrm{H}-3$ LIQ & $\mathrm{pCi} / \mathrm{L}$ & $3.00 E+02$ & $03 / 23 / 82$ & $1.70 E+04$ & \\
\hline $6-28-40$ & $\mathrm{H}-3$ LIQ & $\mathrm{pCi} / \mathrm{L}$ & $3.00 \mathrm{E}+02$ & $06 / 28 / 82$ & $1.80 \mathrm{E}+04$ & \\
\hline $6-28-40$ & $\mathrm{H}-3 \mathrm{LIQ}$ & $\mathrm{pCi} / \mathrm{L}$ & $3.00 E+02$ & $12 / 02 / 82$ & $1.00 \mathrm{E}+04$ & \\
\hline $6-28-40$ & $\mathrm{H}-3 \mathrm{LIQ}$ & $\mathrm{pCi} / \mathrm{L}$ & $3.00 E+02$ & $03 / 24 / 83$ & $9.80 \mathrm{E}+03$ & \\
\hline $6-28-40$ & $\mathrm{H}-3 \mathrm{LIQ}$ & $\mathrm{pCi} / \mathrm{L}$ & $3.00 \mathrm{E}+02$ & $06 / 14 / 83$ & $9.70 E+03$ & \\
\hline $6-28-40$ & $\mathrm{H}-3 \mathrm{LIQ}$ & $\mathrm{pCi} / \mathrm{L}$ & $3.00 \mathrm{E}+02$ & $09 / 12 / 83$ & $9.10 E+03$ & \\
\hline $6-28-40$ & $\mathrm{H}-3 \mathrm{LIQ}$ & $\mathrm{pCi} / \mathrm{L}$ & $3.00 E+02$ & $01 / 06 / 84$ & $1.10 E+04$ & \\
\hline $6-28-40$ & $\mathrm{H}-3 \mathrm{LIQ}$ & $\mathrm{pCi} / \mathrm{L}$ & $3.00 E+02$ & $03 / 30 / 84$ & $1.20 \mathrm{E}+04$ & \\
\hline $6-28-40$ & $\mathrm{H}-3 \mathrm{LIQ}$ & $\mathrm{pCi} / \mathrm{L}$ & $3.00 E+02$ & $06 / 28 / 84$ & $1.30 E+04$ & \\
\hline $6-28-40$ & $\mathrm{H}-3 \mathrm{LIQ}$ & $\mathrm{pCi} / \mathrm{L}$ & $3.00 E+02$ & $09 / 30 / 84$ & $1.20 \mathrm{E}+04$ & \\
\hline $6-28-40$ & $\mathrm{H}-3 \mathrm{LIQ}$ & $\mathrm{PCi} / \mathrm{L}$ & $3.00 \mathrm{E}+02$ & $03 / 25 / 85$ & $9.10 E+03$ & $6.90 E+02$ \\
\hline $6-28-40$ & $\mathrm{H}-3 \mathrm{LIQ}$ & $\mathrm{pCi} / \mathrm{L}$ & $3.00 \mathrm{E}+02$ & $02 / 28 / 86$ & $1.20 E+04$ & $5.30 \mathrm{E}+02$ \\
\hline $6-28-40$ & NITRATE & $M G / L$ & $5.00 \mathrm{E}-01$ & $01 / 17 / 80$ & $9.20 E+00$ & \\
\hline $6-28-40$ & NITRATE & $\mathrm{MG} / \mathrm{L}$ & $5.00 \mathrm{E}-01$ & $03 / 28 / 80$ & $7.80 E+00$ & \\
\hline $6-28-40$ & NITRATE & $\mathrm{MG} / \mathrm{L}$ & $5.00 \mathrm{E}-01$ & $06 / 11 / 80$ & $7.20 E+00$ & \\
\hline $6-28-40$ & NITRATE & $\mathrm{MG} / \mathrm{L}$ & $5.00 \mathrm{E}-01$ & $09 / 04 / 80$ & $1.20 \mathrm{E}+01$ & \\
\hline $6-28-40$ & NITRATE & $M G / L$ & $5.00 \mathrm{E}-01$ & $03 / 23 / 81$ & $8.40 E+00$ & \\
\hline $6-28-40$ & NITRATE & $M G / L$ & $5.00 E-01$ & $06 / 12 / 81$ & $1.00 \mathrm{E}+01$ & \\
\hline $6-28-40$ & NITRATE & $M G / L$ & $5.00 E-01$ & $09 / 09 / 81$ & $5.00 \mathrm{E}-01$ & \\
\hline
\end{tabular}


TABLE 2. (contd)

\begin{tabular}{|c|c|c|c|c|c|c|}
\hline \multirow{2}{*}{ Well Name } & \multicolumn{2}{|c|}{ Constituent } & \multirow{2}{*}{$\begin{array}{c}\text { Detection } \\
\text { Limit } \\
\end{array}$} & \multirow{2}{*}{$\begin{array}{c}\text { Collection } \\
\text { Date } \\
\end{array}$} & \multirow[b]{2}{*}{ Result } & \multirow{2}{*}{$\begin{array}{l}\text { Counting } \\
\text { Error } \\
\end{array}$} \\
\hline & Name & Units & & & & \\
\hline $6-28-40$ & NITRATE & $M G / L$ & $5.00 \mathrm{E}-01$ & $01 / 06 / 82$ & $7.30 \mathrm{E}+00$ & \\
\hline $6-28-40$ & NITRATE & $M G / L$ & $5.00 \mathrm{E}-01$ & $03 / 23 / 82$ & $9.10 \mathrm{E}+00$ & \\
\hline $6-28-40$ & NITRATE & $M G / L$ & $5.00 \mathrm{E}-01$ & $06 / 28 / 82$ & $1.00 \mathrm{E}+01$ & \\
\hline $6-28-40$ & NITRATE & $\mathrm{MG} / \mathrm{L}$ & $5.00 \mathrm{E}-01$ & $12 / 02 / 82$ & $7.20 \mathrm{E}+00$ & \\
\hline $6-28-40$ & NITRATE & $M G / L$ & $5.00 \mathrm{E}-01$ & $03 / 24 / 83$ & $8.90 \mathrm{E}+00$ & \\
\hline $6-28-40$ & NITRATE & $M G / L$ & $5.00 \mathrm{E}-01$ & $09 / 12 / 83$ & $9.60 \mathrm{E}+00$ & \\
\hline $6-28-40$ & NITRATE & $M G / L$ & $5.00 \mathrm{E}-01$ & $01 / 06 / 84$ & $7.90 \mathrm{E}+00$ & \\
\hline $6-28-40$ & Co 60 & $\mathrm{pCi} / \mathrm{L}$ & $2.00 \mathrm{E}+01$ & $01 / 17 / 80$ & $1.60 \mathrm{E}+01$ & \\
\hline $6-28-40$ & CO 60 & $\mathrm{pCi} / \mathrm{L}$ & $2.00 E+01$ & $06 / 14 / 83$ & $8.40 E+00$ & $4.50 \mathrm{E}+00$ \\
\hline-40 & Co 60 & $\mathrm{pCl} / \mathrm{L}$ & $2.00 E+01$ & $09 / 12 / 83$ & $5.10 \mathrm{E}+00$ & $4.10 \mathrm{E}+00$ \\
\hline-40 & Co 60 & $\mathrm{pCi} / \mathrm{L}$ & $2.00 \mathrm{E}+01$ & $03 / 30 / 84$ & $2.90 \mathrm{E}+00$ & $3.20 \mathrm{E}+00$ \\
\hline-40 & CO 60 & $\mathrm{pCi} / \mathrm{L}$ & $2.00 E+01$ & $06 / 28 / 84$ & $1.90 \mathrm{E}+00$ & $3.20 \mathrm{E}+00$ \\
\hline-40 & $\cos 60$ & $\mathrm{pCi} / \mathrm{L}$ & $2.00 E+01$ & $09 / 30 / 84$ & $-3.10 E+00$ & $3.20 \mathrm{E}+00$ \\
\hline 40 & CO 60 & $\mathrm{PCi} / \mathrm{L}$ & $2.00 E+01$ & $03 / 25 / 85$ & $-1.80 E+00$ & $3.30 E+00$ \\
\hline $6-28-40$ & CS 137 & $\mathrm{pCi} / \mathrm{L}$ & $3.00 E+01$ & $01 / 06 / 84$ & $2.70 E+00$ & $3.00 \mathrm{E}+00$ \\
\hline
\end{tabular}

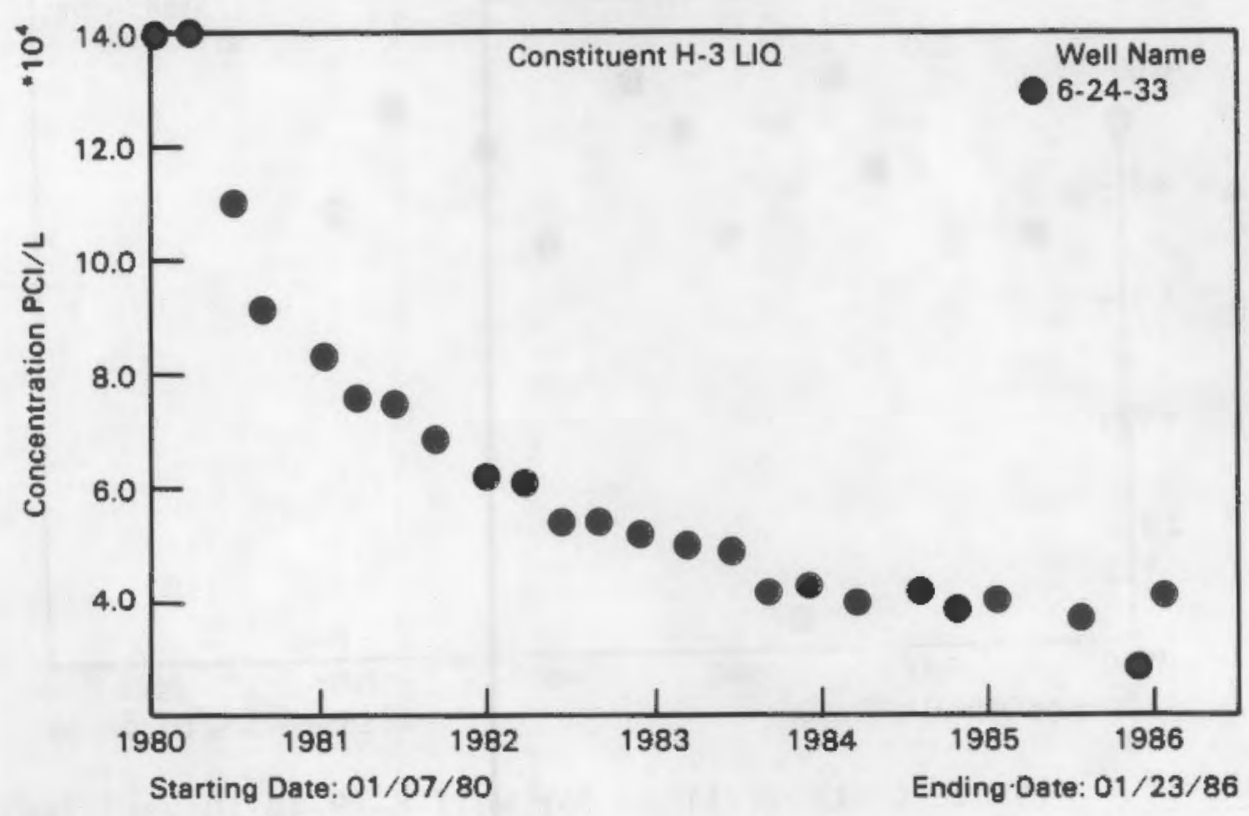

FIGURE 14. Tritium Concentrations for Well 6-24-33 (Unverified) 


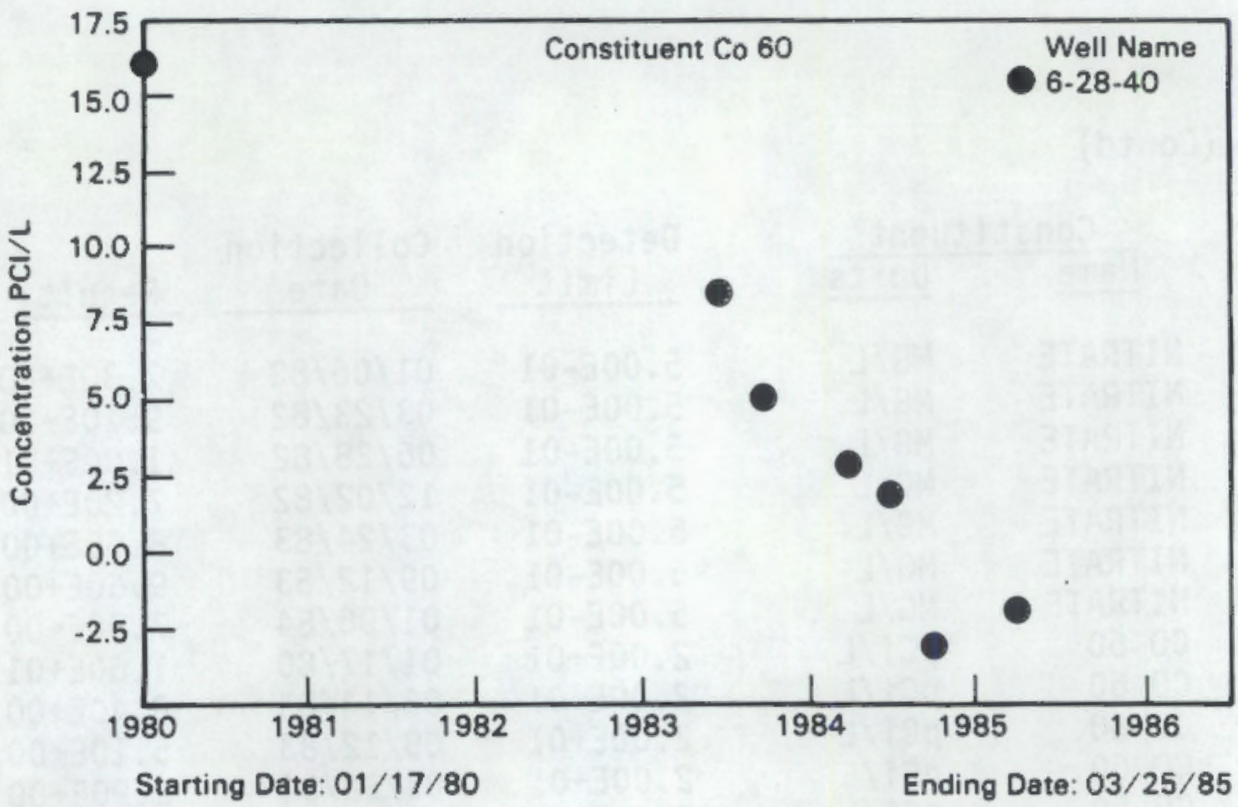

FIGURE 15. Cobalt 60 Concentrations for Well 6-28-40 (Unverified)

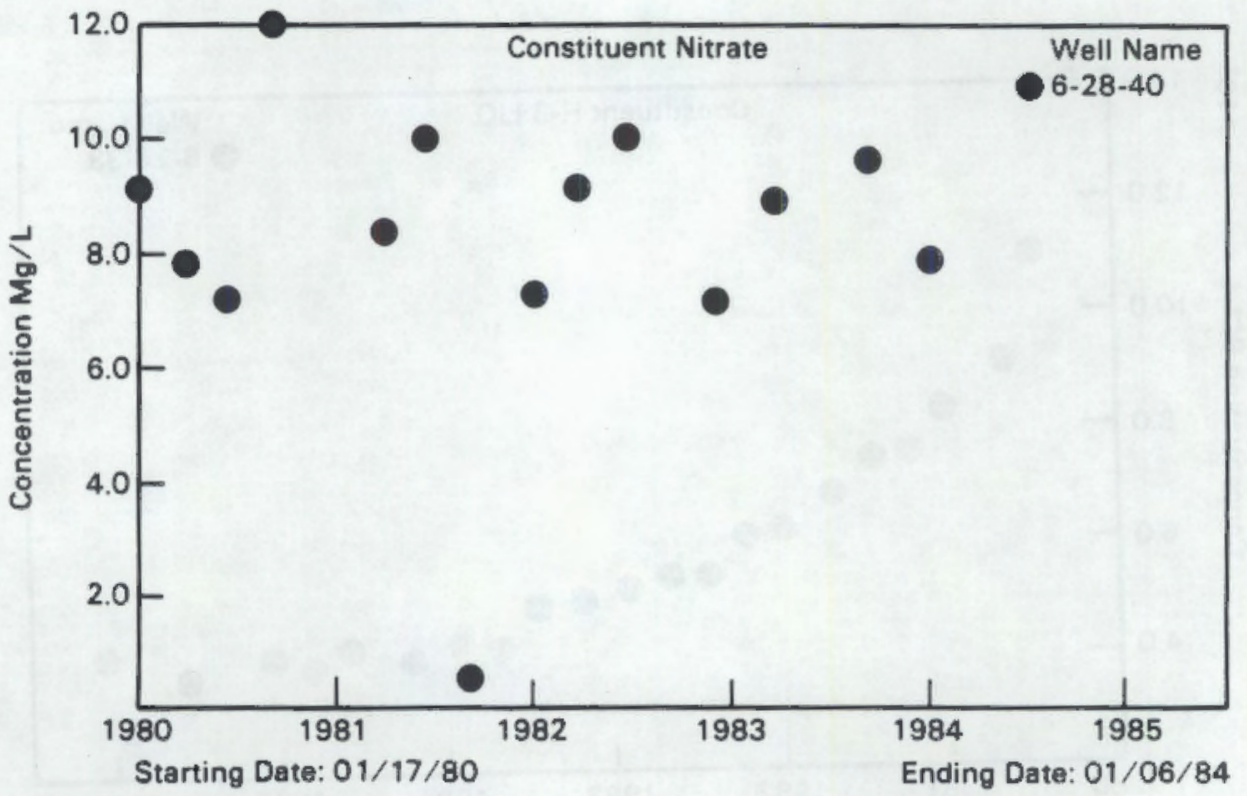

FIGURE 16. Nitrate Concentrations for Well 6-28-40 (Unverified)

for well 6-28-40. These data indicate either no change or slight decreases in the concentrations for the constituents analyzed over the past few years. 
For a further discussion of the significance of these data, refer to the annual ground-water monitoring report for the Hanford Site, published by Battelle, Pacific Northwest Laboratory (PNL) [e.g., PNL-5408 (Cline et a1. 1985)].

\section{Results from the NROW Landfill Drilling}

In general, the results of the drilling to date support previously collected data. The top of the unconfined aquifer (the water table) is slightly less than $125 \mathrm{ft}$ beneath the surface at the NRDW drilling sites. The first lowpermeability clay layer of significance is encountered between 195 and $210 \mathrm{ft}$ beneath the surface. It is approximately $18 \mathrm{ft}$ thick on the west (upgradient) side of the NRDW Landfill, and about $10 \mathrm{ft}$ thick on the east (downgradient) side. This clay layer appears to be a true aquitard, and if its lateral extent continues under the Solid Waste Landfill, the effective thickness of the unconfined aquifer would be 85 to $90 \mathrm{ft}$.

Figure 17 presents a geologic section for the area of the Solid Waste Landfill. The drilling at the NRDW Landfill does not indicate there is anything significantly different in terms of the subsurface geology or hydrology from what is known of nearby areas. The direction of flow appears to be west-northwest to east-southeast, and the gradient is quite low, on the order of tenths of $\mathrm{ft} / 1000 \mathrm{ft}$. 


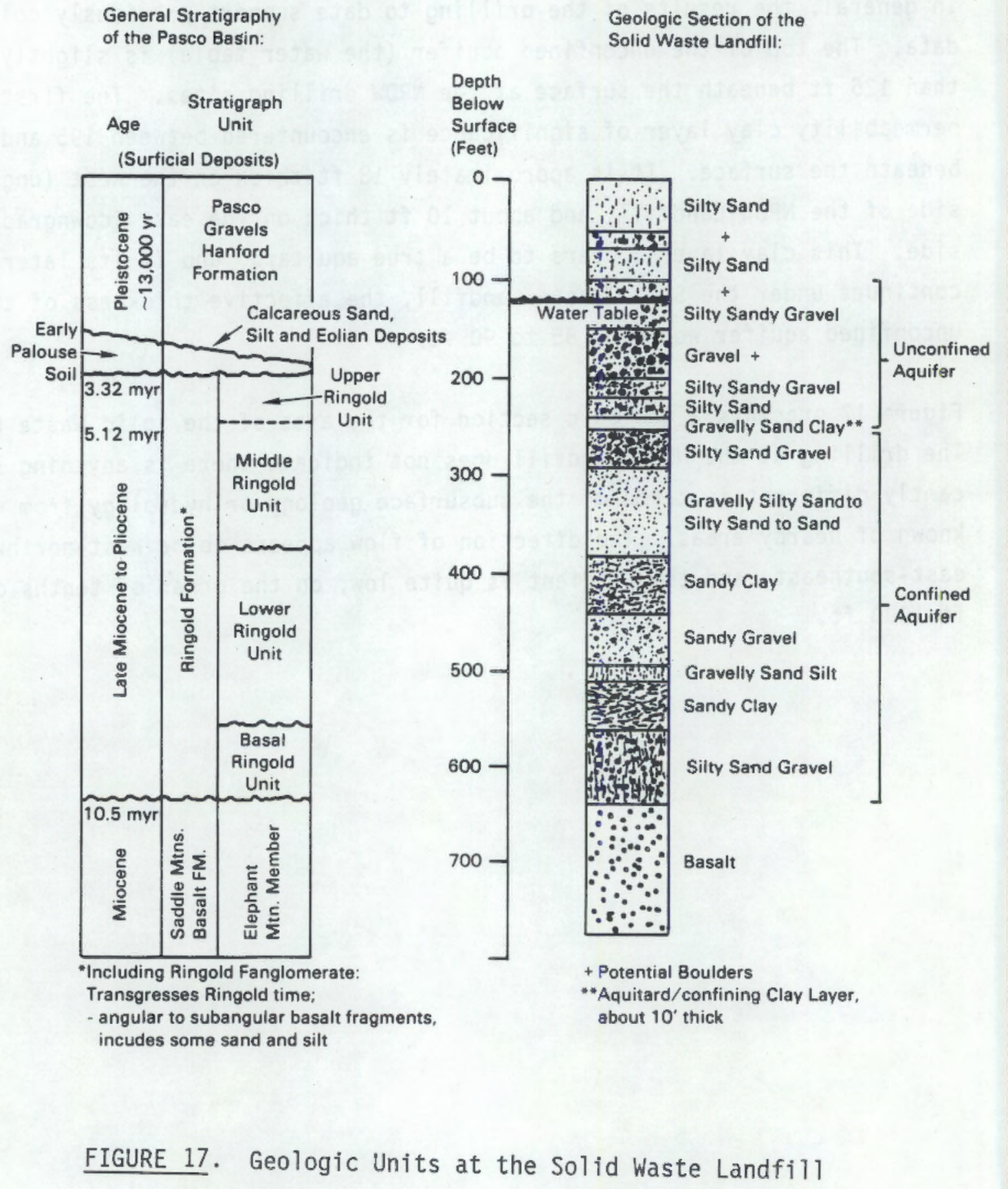




\section{COMPLIANCE PLAN FOR THE SOLID WASTE LANDFILL}

The compliance plan that follows is divided into two parts. The first discusses the planned well installation, including the number of wells, their locations and depths, and pertinent drilling considerations to meet the requirements in WAC-173-304. The second part describes the ground-water monitoring that is planned to begin as soon as the wells are completed. 'A schedule for implementation is also provided.

\section{PLANNED WELL INSTALLATION}

A total of six wells are planned to provide ground-water monitoring at the Solid Waste Landfill site. Figure 18 is a schematic drawing of the Solid Waste Landfill, closed, open, and future sections, with well locations indicated. One upgradient well, and five downgradient wells spaced approximately $500 \mathrm{ft}$ apart from each other, are planned for reasons discussed below.

\section{Rationale}

Because the nine wells associated with the NRDW Landfill are in the same area as those planned for the Solid Waste Landfill, with one shallow and one deep monitoring well upgradient, only one upgradient well for the Solid Waste Landfill is planned. Data from wells at the NRDW Landfill and at the Solid Waste Landfill next to it will be shared by both projects. The first downgradient well will be drilled approximately $500 \mathrm{ft}$ from the last monitoring well for the NRDW Landfill, parallel to the fence. Thereafter, the downgradient wells will be spaced approximately 400 to $500 \mathrm{ft}$ from each other because the climate in the area is arid (only 6 to $7 \mathrm{in}$. of rain annually), and because the waste is non-hazardous and mainly dry.

The upgradient well will be located about 200 to $300 \mathrm{ft}$ outside the Solid Waste Landfill fence; the downgradient wells will be located about $25 \mathrm{ft}$ outside 


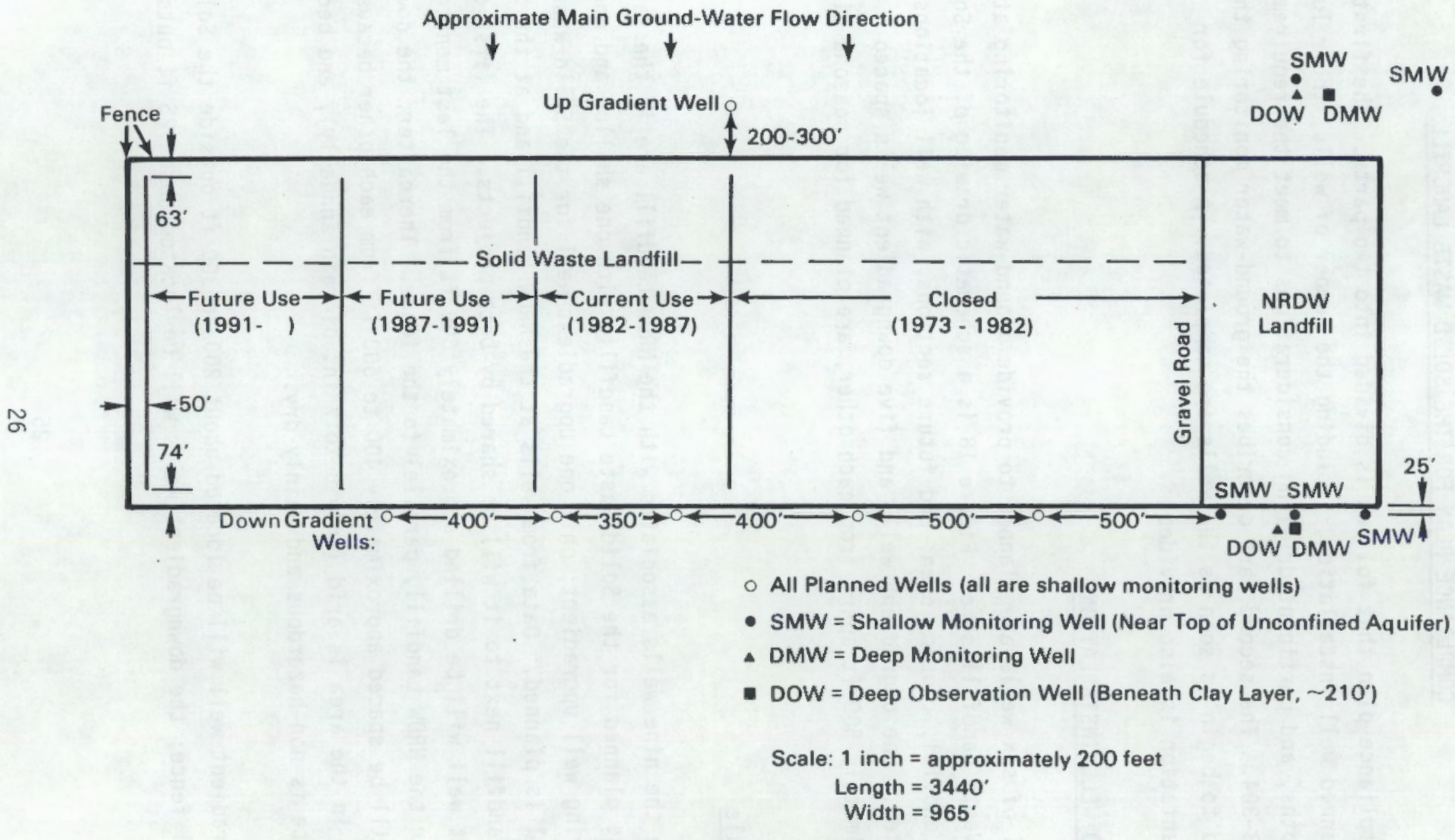

FIGURE 18. Planned Well Installation at the Solid Waste Landfill 
the fence. The purpose of the upgradient well is to allow monitoring of ground water that is not expected to be contaminated by anything from the Solid Waste Landfi11. A distance of several hundred feet from the perimeter fence is planned to ensure that water samples taken from the upgradient well will not be contaminated from anything from the Landfill. This is the same distance at which upgradient wells are being drilled to meet the approved ground-water monitoring plan for the NRDW Landfill. However, for the downgradient wells, it is desirable to be as close as possible to the Landfill in order to detect any contamination as soon as possible. Therefore a distance of about $25 \mathrm{ft}$ from the perimeter fence is planned. This distance should be sufficiently far away from the waste so that the drilling and the wells will not introduce any contamination from the Landfill to the ground water, but at the same time, close enough to detect any contamination before any deleterious effects would be detected further downgradient. This distance is also the same distance planned in the approved ground-water monitoring compliance plan for the NRDW Landfill.

\section{Completion Depths}

Each well will be completed to the top of the unconfined aquifer, which is approximately $125 \mathrm{ft}$ beneath the surface. The screened lengths will extend about 10 to $15 \mathrm{ft}$ into the aquifer. Figure 19 shows a schematic drawing of a shallow monitoring well. The figure is not to scale and does not attempt to show exact details of well construction. Exact measurements such as completion depths, amount of materials used, joints, spacing, etc. shall be determined in the field during drilling.

\section{Wel1 Construction Details}

For the small number of wells needed for this monitoring project, a drilling contractor using one cable tool rig to drill the wells more or less consecutively may be employed. One advantage to proceeding in this manner is that the experience gained at one well can be incorporated into drilling the next well. The driller will be required to provide proof of qualifications and experience and will be supervised during drilling. The driller should 


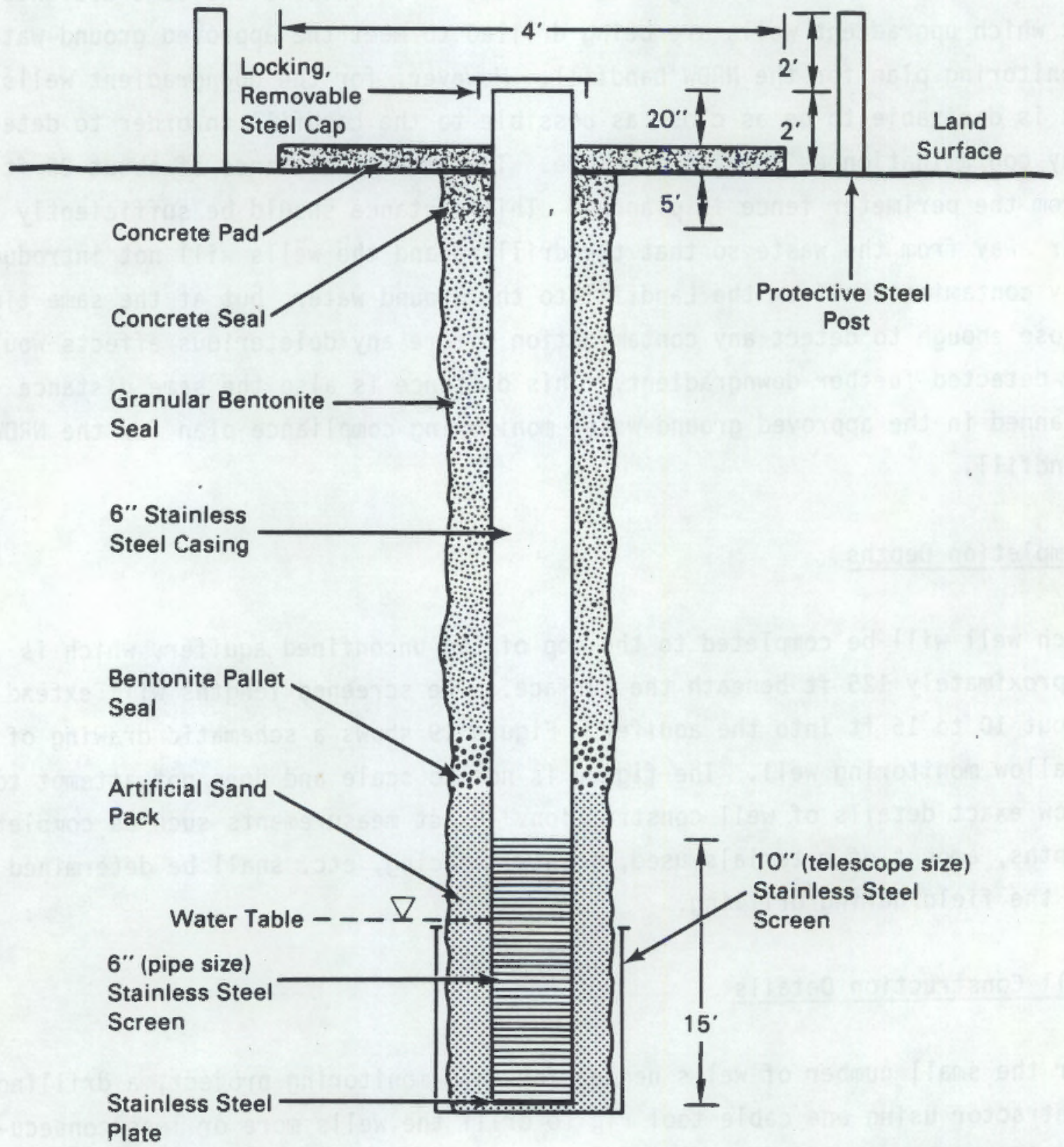

*Not to Scale

FIGURE 19. Example of a Shallow Monitoring Well 
know how to deal with "heaving sand" during drilling, and from the drilling experience at the NROW Landfill, the driller can expect to encounter boulders (river rock with diameters in excess of $6 \mathrm{in.)}$, very hard clay layers, and caliche layers (capable of acting as a natural cement). Well drilling specifications will be presented in a separate document.

Care will be taken to ensure that the wells are properly installed and that contamination is not introduced during drilling, because these wells will be used for gathering water-quality data. Therefore, all equipment, casings, and screens will be steam-cleaned prior to use and kept off the ground. Driling will probably be done by the cable tool method. A drive barrel will be used as long as possible above the water table. Hard tools can be used when necessary, but only approved additives will be used. These tools can be used when a gravel/boulder layer requires them, but as soon as the hard layer is penetrated, the driller should return to a drive barrel operation.

The wells will be completed using flush-coupled, 6-in. diameter or smaller stainless steel (Type 304) casings and screens. The casings will consist of Schedule 10 pipe with Schedule 40 couplings. During drilling, 10-in. inner diameter temporary carbon steel casings will be used to hold the hole open. A I0-in. telescope-size stainiess steel screen will be set for testing purposes when the well has reached the completion depth, and the temporary casing will be pulled back to expose the screen. The well will then be developed and tested. Following testing, the screen will be left in place and the 6-in. assembly casing/screen will be placed inside. An artificial sand pack will be set between the screens and will extend $5 \mathrm{ft}$ above the top of the 6-in. screen. The annular space above the sand pack will be sealed with a $5-\mathrm{ft}$ layer of bentonite pellets. A seal of granular bentonite will fill the remaining annular space up to $5 \mathrm{ft}$ below the land surface, where a concrete seal will be emplaced. The well will be finished with a concrete pad, removable locking cap, and protective steel posts. Following completion, each new well will be surveyed to obtain the location coordinates and the elevation of the top of the casing. The wells will then be given permanent numbers assigned according to Hanford Site conventions. 


\section{Hydrogeologic Testing and Characterization}

Under the guidance of a geologist, rock and soil samples will be collected at 5-ft intervals and at changes in lithology. Materials encountered above the water table will be described as hand specimens in geologic field records. Typical descriptions will include estimated grain size, color, and mineralogy of major constituents. A dual sample will be collected, with one specimen submitted for laboratory analysis and another specimen retained for archiving. The following laboratory tests will be conducted at selected horizons:

1) grain size distribution based on sieve analysis, 2) bulk porosity, and 3) petrographic descriptions of mineral content. For materials taken from below the water table, additional tests will be conducted: vertical and horizontal permeability tests on materials that can be sampled in a sleeved drive barrel, and chemical analyses ( $\mathrm{pH}, \mathrm{Eh}, \mathrm{CaCO}_{3}$, etc.).

All wells will be logged following completion, using geophysical tools. The suite of logs to be made will include natural gamma, neutron-epithermalneutron, and gamma-ganma. These logs give an indication of the properties of the materials around the borehole, and they provide a relatively objective and continuous record of the materials penetrated. Therefore, they are a useful supplement to the sample descriptions provided by the geologist present during well installation. The types of information that will be obtained from the geophysical logging effort are described below.

Each of the three geophysical tools named above gives different information concerning the subsurface geology. The neutron-epithermal-neutron probe has a neutron source and a detector. The neutrons emitted interact with hydrogen in the water contained in the pore spaces of the sediments, and the log produced gives an indication of the moisture content of the sediment layers above the water table, as well as of the saturated porosity of the layers below the water table. The gamma-gamma probe contains a source of gamma radiation and a detector. The gamma photons emitted are scattered and absorbed by the materials through which they pass, and the resulting log gives an indication of the bulk density of these materials. The natural gamma probe contains 
only a detector. It measures the natural radiation emitted by the sediments; the log produced gives an indication of the clay content, or, where the ground water contains radionuclides, the level of contamination.

Collection of water Tevel measurements will continue at the site during and following well drilling. Aquifer testing will be conducted on all of the wells being installed.

The new wells will be developed immediately following completion and will be equipped with samping devices within 90 days.

\section{Vadose Zone Sampling}

Samples of unsaturated material will be collected from each well in a sleeved drive barrel or a split-spoon device. These samples will be sealed in waterproof containers at the drill site and submitted for laboratory analysis of in situ soil moisture. At some horizons, boulders may prevent sample collection because of the water required for hard tool drilling. Samples collected in soft or flowing sand units are commonly too disturbed to reconstitute in situ permeabilities. If such units are encountered, some loss of data may occur. Reconstituted samples may be run to determine hydraulic conductivity in selected horizons. Soil moisture retention analysis will be conducted on a selective basis. Particle density (specific grain density) will be measured selectively for use in determining bulk sample densities and porosities.

\section{GROUND-WATER MONITORING}

Field measurements and sample collection will begin as soon as the wells are developed and the collection equipment (pumps, bailers, sample labeis, bottles, etc.) are availabie and in place.

\section{Field Measurements}

Ground-water samples will be collected on a quarterly basis according to established procedures in use for other ground-water monitoring projects at 
the Hanford Site (Appendix A). The ground-water surface elevation will be measured each time the well is sampled, as required by the WAC 173-304 regulations. However, to obtain meaningful measurements, the water levels for the wells monitoring both the NRDW and the Solid Waste Landfills also may need to be measured separately from the sample collection because scheduled sample collection for analysis from all of the monitoring wells may take more than one day to complete. The water table levels need to be measured on the same day to avoid spurious results from changing water levels.

Sampling Preparation

Pumps and procedures used will ensure that the samples collected are representative of the ground water. Each well will have a dedicated submersible pump used for purging the well and for collection of samples. This purmp is adequate for all analyses with the possible exception of Total Organic Carbon (TOC), which will require a Teflon ${ }^{\text {TW }}$ bailer.

Sample Collection

On the Hanford Site, all ground-water monitoring samples are collected by trained Environmental Radiation Protection Technologists (RPT's) using PNLapproved written procedures (PNL MA-580; see Appendix A). After the required water level measurement is taken, the well is purged for a calculated period of time, based on removal of 3 borehole volumes. For added ensurance that: the stagnant water has been removed from the well, the $\mathrm{pH}$, specific conductivity, and temperature are checked for stabilization via periodic measurements taken as the well is purged. All of these measurements are recorded in the field logbook, but only the final set of measurements is used for reporting purposes.

Teflon is a registered trademark of E.I. DuPont de Nemours Co., Wilmington, Delaware. 
Sample Preservation

Appropriate sample preservation techniques will be used to help ensure that the analytical results obtained by the analytical laboratory have not been affected by alteration of the sample after collection. The preservation techniques to be used include $\mathrm{pH}$ control, chemical addition, and temperature control. A summary of the techniques applied for each of the analyses is given in Table 3. In accordance with recent EPA guidelines, two aliquots will be collected for metals analysis. One will be filtered and analyzed for dissolved metals, and one will be analyzed for total recoverable metals without filtering.

Chain-of-Custody

Chain-of-custody procedures witl be followed to ensure the integrity of the samples from the time of collection through data reporting (Appendix A).

These procedures provide specifications for labeling, sealing, and tracking the samples. As required, documentation, including field logbooks and chainof-custody forms, will be maintained.

$\underline{\text { Sample Analyses }}$

The water measurements and constituents for which analyses are required by state regulations WAC 173-304 are listed in Table 4.

The test methods to be used (required by WAC 173-304) are as specified in the EPA Publication SW-846, Test Methods for Evaluating Solid Waste - Physical/ Chemical Methods (1982) with the exception of the method for coliform, which will use the method specified in the most recent edition of Standard Methods for the Examination of Water and Wastewater (American Public Health Association 1985). Table 3 provides more detailed information. 
TABLE 3. Standard List of Analyses for the Solid Waste Landfili Ground-Water Monitoring Effort

\begin{tabular}{|c|c|c|c|c|}
\hline Constituent $\mathrm{C}$ & Collection(a) & Preservation(b) & Method & $\begin{array}{c}\text { Detection } \\
\text { Limit (c) } \mu \mathrm{g} / 1 \\
\end{array}$ \\
\hline Manganese & $\mathrm{P}$ & $\mathrm{HNO}_{3}$ to $\mathrm{pH}<2$ & $S W-846, \# 6010$ & 5 \\
\hline Iron & $"$ & $"$ & $"$ & 50 \\
\hline Zinc & $"$ & $"$ & $"$ & 5 \\
\hline Nitrate ${ }^{(d)}$ & $"$ & None & IC $(e, f)$ & 500 \\
\hline Sulfate & $"$ & $“$ & $"$ & $"$ \\
\hline Chioride & $"$ & $"$ & $"$ & $"$ \\
\hline $\begin{array}{l}\text { TOC } \\
\text { (Total Organi } \\
\text { Carbon) }\end{array}$ & $i c^{G}$ & $\mathrm{H}_{2} \mathrm{SO}_{4}$ to $\mathrm{pH}<2$ & $\begin{array}{l}\text { Std. Methods, } \\
\# 505\end{array}$ & 1000 \\
\hline $\begin{array}{l}\text { Ammonjym } \\
\text { Ion }\end{array}$ & G & $\mathrm{H}_{2} \mathrm{SO}_{4}$ to $\mathrm{pH}<2$ & $\# 417, \mathrm{~A}-\mathrm{E}$ & 50 \\
\hline $\begin{array}{l}\text { Coliform } \\
\text { Bacteria }\end{array}$ & $\mathrm{p}$ & None & $\# 908 \mathrm{~A}$ & $2.2 \operatorname{MPN}(g)$ \\
\hline Temperature & Field Measu & rement & & $0.1^{\circ} \mathrm{C}$ \\
\hline $\begin{array}{l}\text { Specific } \\
\text { Conductance }\end{array}$ & Field Measu & rement & & $1 \mu$ mho \\
\hline $\mathrm{pH}$ & Field Measu & rement & & $0.01 \mathrm{pH}$ \\
\hline
\end{tabular}

(a) $P=$ plastic, $G=$ glass.

(b) All samples will be cooled to $4^{\circ} \mathrm{C}$ upon collection.

(c) Detection limit units unless otherwise indicated.

(d) Nitrate, Nitrite and Ammonia as Nitrogen.

(e) In-house analytical method.

(f) IC = ion chromatography.

(g) $M P N=$ most probable number.

\section{Quality Assurance}

Quality assurance (QA) for the Solid Waste Landfill ground-water monitoring program will be conducted in accordance with an PNL-approved plan. This plan will be followed, with assistance and direction being provided by the responsible Quality Engineer. 
TABLE 4. Water Measurements and Constituent Analyses Required by State of Washington Regulation WAC 173-304 for Ground-Water Monitoring of Solid Waste Landfills

\author{
Ground Water Surface Elevation \\ Temperature \\ Conductivity \\ $\mathrm{pH}$ \\ Chioride \\ Nitrate, Nitrite, and Ammonia as Nitrogen \\ Sulfate \\ Dissolved Iron \\ Dissolved Zinc and Manganese \\ Chemical 0xygen Demand \\ Total Organic Carbon (TOC) \\ Total Coliform
}

\title{
Quality Control
}

The purpose of this quality control (QC) effort is to determine and document the quality of the analytical results being produced by the laboratory and to institute corrective actions as needed. The quality control effort has two main components: 1) routine internal checks performed by the analytical laboratory, and 2) external checks to independently evaluate the laboratory's performance.

The internal QC effort for inorganic analyses will include standard curves, a verification of standards every 20 samples, a blank for each extraction batch, and a random matrix spike for $10 \%$ of the samples. For organic analyses, the general QC requirements will include a 5-point curve, verified every 12 hrs: a random matrix spike for $10 \%$ of the samples; a blank for each extraction batch; and internal standards and surrogates. Data obtained from the matrix spikes, blanks, and surrogates will be presented in control charts, which will indicate whether or not a process is in statistical control.

The external QC effort to evaluate the laboratory's performance will require interlaboratory comparisons as well as submission to the analytical laboratory of spiked samples, repilicates, and blanks. 
Data Handling and Verification

Analytical data obtained from laboratory measurements are entered into a computerized system and subsequently are transferred to the applicable data base via magnetic tape. Rigorous data handling and verification procedures will be required to ensure that errors are not made during entry or transfer.

\section{Analytical Laboratory}

The analytical laboratory will enter relevant information concerning sample analysis into logbooks maintained for each analytical procedure. This information may include calibration data, sample data, instrument conditions, matrix spike recoveries, standards preparation, and so on. other data needed to support sample results, such as chromatograms, charts, tables, etc., will be labelled and stored in a secure area.

Sample data generated $w 11$ be entered into a main computer by a data handler. The data sheets provided by the analysts for this purpose will include sample identification, sample results in appropriate units, the extraction date (if any) and analysis date; dilutions (if any), matrix spike recoveries, reagent blank results, and any other QC results. A copy of the analysts' data sheets will be provided to the laboratory supervisor or director for review.

The data will be entered using written procedures. Discrepancies and anomalies will be resolved at this time. For all analyses except TOC, all results below the contractual detection limits will be entered as equal to the detection limit. For TOC, the exact results will be entered into the computer. A flag will automatically be set by the computer for all results at or below the detection limit. This flag will become a "less than" sign when the tape is loaded onto the data base. After all data for a sample set have been entered, an internal report will be generated to verify that the data have been correctly entered. If corrections are needed, a second report will be generated for verification. Finally, the data will be copied onto a magnetic tape. A hardcopy report will be generated from the tape and delivered to the data base 
manager with the tape. Deliveries of data from the Solid Waste Landfill groundwater monitoring will generally be within the 25 business days provided in the analytical contract.

\section{Hanford Ground-Water Data Base}

Analytical data received on magnetic tape will be inmediately entered into the Hanford Ground-Water Data Base. This computerized data base, kept on a DEC VAX, is used to store analytical and hydrological data, hydrographs, well-structure descriptions, well names (including old well names), well codes, well locations, and drilling logs for Hanford Site wells. Field measurements will be entered manualiy. Once entered into the data base, the laboratory and field data can be accessed for manipulation and evaluation using various programs, or they can be printed out in different formats.

Tests will be conducted to ensure that each data field contains only permissible values. As data are entered, the values in a field (such as the well code field) will be checked against a list of allowable values; the record will be rejected if there is not a match, and will be investigated to determine appropriate action.

Additional verification of the data will be accomplished by manually checking each data point (received on tape from the laboratory) against a hard-copy record provided by the laboratory. A special field in the data base, containing the initials of the person conducting the verification, will be used to denote that a given data point has been checked. Discrepant data identified through

TW DEC VAX is a registered trademark of the Digital Equipment Corporation, Maynard, Massachussetts. 
this process will be flagged for further investigation, usually involving communication with the Taboratory. This time-consuming process helps to ensure that the data contained in the data base have not been altered during transfer and entry.

An initial data evaluation procedure will involve a test for outliers that will be conducted following entry of the analytical and water level data. These tests involve checking each new data point for a particular well against the trend set by that well's recent history, using the programs ANATREND and HYDTREND, respectively, for analytical and water level measurements. Based on the established linear trend for a well (it requires 10 analyses to establish a trend), the programs compute the predicted values for the next sampling date and set upper and lower limits. Approximately $95 \%$ of the values are expected to fall within these limits, and a new data point will be considered to be an outlier if it falls outside of these limits. Printouts from these programs will be generated, and any apparent problems will be resolved as necessary. An additional statistical discussion is included in Appendix B.

\section{Data Evaluation}

Raw data, plots, and summarized data will be provided to aid in the evaluation of the data. Either a properly conducted t test, or some other suitable statistical test or procedure will be used to detect any differences in upgradient and downgradient ground-water concentrations. An annual report will be submitted by March 1 of each year to the regulating agencies that will include the estimated ground-water flow rate and direction of movement in the unconfined aquifer. Statistical analyșes of QC data will be conducted to ensure problems in the laboratory are quickly identified.

It will require at least a year's sampling to provide enough data for meaningful statistical analyses. When enough data are available, a qualified statistician will provide a statistical evaluation within about 2 mo of sampiing (Appendix B). A 2-mo period is needed to accomplish all of the steps involved, including sample analysis, data entry, and statistical data evaluation. Normally, the analytical laboratory is allowed by contract 25 working days 
(about $5 \mathrm{wk}$ ) to conduct the analyses and report the results. Once the analytical data are received from the laboratory, it can take at least a-week to enter the data into the data base and complete preliminary checks. Finally, several weeks are required to perform the statistical evaluation and prepare a report containing the results.

If there is a statistically significant increase in any constituents, the Benton-Franklin Health Department will be notifjed within 7 days of receiving the statistical evaluations of sample data. The monitoring wells for the Solid Waste Landfill will be resampled immediately to determine the concentrations of al1 the constituents listed in WAC 173-304 and to determine if there is a statistically significant change over background level so that the groundwater performance standard defined in WAC 248-54-165 has been exceeded. The Benton-Franklin Health Department will be notified within 14 days of date of receipt of these results. Appendix $C$ contains the relevant section, WAC 173304-490, from Chapter 173-304 WAC, 1985 WAC Supplement. This section presents the ground-water monitoring requirements for solid waste landfills. 



\section{REFERENCES}

American PubTic Health Association (APHA). 1985. Standard Methods for the Examination of water and Wastewater. APHA, Wastington, D.C.

Eaker, V. R., and D. Nummedal, eds. 1978. "The Channeled Scabiand." In A Guide to the Geomorpholcay of the Columbia Basin, Washington. Prepared for tine Comparative planetary Geology Field Conference ineld in the Columbia Basin, June 5-8. Planetary Geology Program, Office of Space Science, National Aeronautics and Space Administration, Washington, D.C.

Barrash, W., J. Sond, R. Venkatakrishnan. 1983. "Structural Evolution of the Columbia Plateau in Washington and Oregon." Am. Jour. Sci., 283:897-935.

Bierschenk, W. H. 1959. Aquifer Characteristics and Ground-Water Movement at Hanford. HW-60601, General Electric Company, Richland, Washington.

Cline, C. S., J. T. Rieger, and J. R. Raymond. 1985. Ground-water Monitoring at the Hanford Site, January-December 1984. PNL-5408/UC-41,11, Pacific Northwest Laboracory, Richland, Washington.

Environmental Protection Agency (EPA). 1982. Test Methods for Evaluating Solid Waste--Chemical/Physical Methods. SW-846, EPA, Washington, D.C.

Gephart, R. E., R. C. Arnett, R. G. Baca, L. S. Leonhart, and F. A. Spane, Jr. 1979. Hvdrologic Studies Within the Columbia Plateau, washington: An Integration of Currant Knowledge. RHO-BWI-ST-5, Rockwell Hanford Operations, Richland, Washington.

Tallman, A. M., K. R. Fecht, M. C. Marratt, and G. V. Last. 1979. Geology of the Separational Areas, Hanford Site, South-Central Washington. RHO-ST23, Rockweli Hanford Operations, Richland, Washington.

U.5. Department of Energy (OOE). 1986. Compliance Ground-water Monitoring Plan for the Non-gadioactive Dangerous waste tandfill on the hanford Site. DOE, Richland, Washington.

Waters, A. C. 1961. "Stratigraphic and Lithologic Variations in the Columbia River Basalt." Am. Jour. Sci., 259:583-611. 
$$
\text { - }
$$ 


\section{APPENDIX A}

SAMPLING PROCEOURES 


\section{APPENDIX A}

\section{SAMPLING PROCEDURES}

This appendix gives procedures to be followed for sample collection, chain- of-custody, and field measurements. These are the same procedures used in compliance monitoring for the Resource Conservation and Recovery Act (RCRA).

A. 1 


\subsection{HAZARDOUS MATERIALS SAMPLING}

Introduction

Environmental monitoring for a wide variety of hazardous chemicals has recently been implemented at the Hanford Site. Samples to be analyzed for these materials must, in many cases, receive special treatment. Accordingly, new procedures that are specifically designed to preserve the integrity of these samples have been developed.

The procedures to be used during collection and transportation of the sampies are contained in this section. All aspects of sampling, including pump operation, borehole purging, and field measurements (water level, pH, specific conductivity, and temperature) are described. The chain-of-custody procedures used to track and protect the samples are also included. 


\subsection{WATER-LEVEL MEASUREMENT PROCEOURE}

Introduction

Equipment

Graduated Steel Tape Method
Water-level measurements are taken each time a well is sampled, before it is purged. These measurements are taken as depth-to-water from the top of the well casing. They must be subtracted from the surveyed elevation of the casing given in Hanford Wells to obtain the elevation of the water table. The water-table elevations obtained for all wells in the sampling network during a particular sampling episode can be used to produce a contour map showing the ground-water surface at the time that the measurements were made. These contour maps can be used to help characterize the ground-water flow system and to ensure that the sampling network is adequate.

Graduated steel measuring tapes are more accurate than electrical tapes and so should be used for official measurements. However, an electrical tape can be used to determine the approximate depth to water.

The following equipment will be needed:

- steel measuring tape with attached weight

- blue carpenter's chalk

- a copy of Hanford Wells (PNL-5397)

- electrical tape

- engineer's measuring tape

- field record forms.

Chalk the l-ft section of steel tape below the zero reading point.

Find the elevation of the measuring point and the estimated water level in Hanford Welis, or use an electric tape to find the approximate depth to water.

Lower the steel tape from the we $11^{\prime}$ 's measuring point (marked with paint on the top of the casing) to the estimated water level. Note the amount of tape that is in the well by reading the tape at the measuring point. This value is referred to as the "hoid point."

Remove the steel tape and check the wetted portion below the zero reading point.

NOTE: If the chalked portion is not wet, repeat the procedure, but allow more of the tape to go down the well (i.e., use a greater hold point).

Add the unwetted length of the chalked portion of the tape to the hold point value to obtain the depth-to-water measurement.

$$
\text { A. } 3
$$


Electric Tape Method
If the chalked portion is not wet, repeat until the water level is marked on the chaiked portion of the tape.

Repeat the procedure unti\} two stee 1 tape measurements agree within $\pm 0.05 \mathrm{ft}$.

Record the depth-to-water measurements, time of measurements, measuring device, and the name of the person taking the measurements on the field record form.

Lower the electric tape from the measuring point into the borehole until the buzzer and the light indicate contact with the water.

Mark the electric tape at the measuring point and identify the nearest graduation on the electric tape.

If the water level is deeper than the nearest graduation marked on the tape, add the difference to the depth identified to obtain the true depth to water.

If the water level is shallower than the nearest graduation marked on the tape, subtract the difference from the depth identified to obtain the true depth to water.

Record the depth-to-water measurements, time of measurements, measuring device, and the name of the person taking the measurements on the field record form.

NOTE: This measurement should be used only as an approximate depth to water, because the electric tape is less reliable than the steel tape. 


\subsection{HAZARDOUS MATERIALS SAMPLE COLLECTION PROCEDURES}

Introduction

Equipment

Sampling

Precautions
These procedures are intended for use in collecting ground-water samples that will be analyzed for hazardous chemicals.

The following equipment may be needed in the field during sampling:

- truck-mounted air compressor and generator

- bladder-pump controlier box

- bladder-pump hoses (set of 2)

- extra discharge line for biadder pump

- extra discharge line for submersible pump

- Tefion bailer

- $\mathrm{pH}$ and conductivity meter

- digital thermometer

- steel measuring tape

- blue chalk

- electrical tape

- engineer's measuring tape

- a copy of Hanford Welis (PNL-5397)

- stopwatch or watch with second hand

- bucket or jug (for measuring flow rate)

- distilled water

- ziplock bags

- ice chests with ice

- plastic gloves

- aprons

- towels

- inde]ible marker

- extra sample labels

- sample seals

- a copy of all relevant procedures

- sample containers with caps and liners (including extras)

- field record forms

- chain-of-custody forms

- sample-analysis request forms.

Do not smoke, eat, or handle any objects not necessary for sampling while performing sampling procedures.

Do not sample downwind of any potential sources of volatile organics such as car exhausts or open fuel tanks. These could contaminate the sample. If any such sources are unavoidable, make a note of them on the field record forms.

Leave caps on the sample containers until just before filling.

Avoid handling the Teflon bottle cap liners. Do not use any liner that falls out of the cap and onto the ground.

$$
\text { A. } 5
$$


Sample collection Using Submersible Pump
Wear gloves when taking:samples and when handling containers, especially those with added preservative.

Take water-leve! measurements according to the water level measurement procedure.

Check to see that the hose bibb for the submersible pump is open.

CAUTION: Be sure the power switch to the $230-V$ outlets is turned off!

Plug the power cord into one of the $230-V$ outiets on the generator on the truck and into the outlet at the well head.

Start the electric generator.

Turn the power switch on to begin pumping process. Be sure not to handle energized power cords. If the pump does not work properly, as indicated by a lack of air flow out the discharge hose or by failure of the generator to "lug" down, turn the switch off immediately. After waiting a few seconds, turn the switch on and off several times rapidiy, finally pausing in the ON position to determine if the pump has started to function properly.

After the water begins to flow from the outlet, pump the well for the length of time indicated in Table 13.I (or for an adjusted pumping time, as explained in Table 13.1), and until $\mathrm{pH}$, temperature, and specific conductivity stabilize. If the well being sampled is not listed in the table, pump for a minimum of 15 minutes and check for stabilization of the $\mathrm{pH}$, temperature, and specific conductivity.

NOTE: Some wells pump down after a period of time. If the welt pumps dry while purging, it does not generaliy mean that a sample cannot be collected. A sample can still be obtajned by following these steps:

1. Turn off the submersible pump when the we 11 pumps dry.

2. Wait for the well to recharge. This should be about 15 minutes, but may take as long as 30 minutes.

3. Measure the depth to water using the electrical tape. Make sure that the water level is above the pump intake.

4. Turn the submersible pump back on. Collect the samples that are designated for collection with the submersible pump.

A. 6 
Table 13.1. Calculated Pumping Times

\begin{tabular}{|c|c|c|}
\hline Well & Number & Calculated Time (min) \\
\hline (199) & H3-I & 24 \\
\hline & $\mathrm{H} 4-3$ & $5 \star$ \\
\hline & $\mathrm{H} 4-4$ & 4 * \\
\hline & $\mathrm{H} 4-5$ & $8^{\star}$ \\
\hline & H4-6 & $5 \star$ \\
\hline (399) & $1-1$ & 30 \\
\hline & $1-2$ & 42 \\
\hline & $1-3$ & 25 \\
\hline & $1-4$ & 34 \\
\hline & $1-5$ & $4^{*}$ \\
\hline & $1-6$ & $6^{\star}$ \\
\hline & $1-7$ & 17 \\
\hline & $1-8$ & 29 \\
\hline & $2-1$ & 32 \\
\hline & $3-7$ & 60 \\
\hline & $3-10$ & 18 \\
\hline & $4-1$ & 35 \\
\hline & $4-7$ & 35 \\
\hline & $8-2$ & 33 \\
\hline (699) & $530-E 15 A$ & 9 * \\
\hline & $\$ 19-\varepsilon 13$ & $12^{*}$ \\
\hline
\end{tabular}

* A]l wells will be pumped a minimum of 15 minutes, eyen if the calculated time is less.

NOTE: These pumping times are based on voiding three bore-volumes of water from the well at a pumping rate of $10 \mathrm{gpm}$. To calculate an adjusted pumping time based on a field measurement of flow rate:

1. Divide the size of the container (in gal) by the number of seconds it took to fill. Multipiy by 60 to get the new pumping rate (per minute).

2. Multipiy the calculated time given in Table 13.1 by 10 and then divide by the new pumping rate to get the new pumping time.

$$
\text { A. } 7
$$


Sample Coliection Using Bladder Pump
Measure the $\mathrm{pH}$, temperature, and specific conductivity of the discharged water at least three times during purging, according to the standard procedures for measuring $\mathrm{pH}$ and conductivity. The $\mathrm{pH}$ will be considered stable when two consecutive measurements agree within $0.2 \mathrm{pH}$ units. Temperature will be considered stable when two consecutive measurements agree within $-0.2^{\circ} \mathrm{C}$. Conductivity will be considered stable when two consecutive measurements agree within 10 umhos. If $\mathrm{pH}$, temperature, and conductivity do not stabilize within the calculated purging time, contact the technical supervisor before collecting samples.

Enter time, date, and your initials on all sample labels.

Record information on field record form as it becomes avajlable. The information that must be recorded on the fieid record forms is described in Section 13.3 (Chain-of-Custody Procedures).

Check the labels on the sample containers to determine which ones can be filled using the submersible pump. (A blue line on the right side of the sample label indicates that the submersible pump should not be used to fill that particular container.)

Fil1 the appropriate sampie containers as described under "Genera\} Sampie Collection Procedure."

Attach a sample seat to each container and place it in a cooler or ice chest.

If the well has a dedicated bladder pump, turn on the air compressor and use the procedure described below. If the we 11 does not have a biadder pump, use the procedures given for the Tefion bailer to collect the remaining samples.

Attach the compressor to the bladder-pump pressure iniet on the face of the controller panel, using the female portion of the coupling supplied.

Connect either end of the controller's red air hose to the pump supply on the right side of the control panel. Connect the other end of the controller air hose to the quick-connect nipple located in the well cap assembiy.

Attach the appropriately iabeled extension line to the biadder-pump discharge line.

Five to fifteen pumping cycles are required to purge the air from the bladder pump and tubing. Full water flow from the sample suppiy tube should then begin. After water fiows from the outiet tube, run the bladder pump for at least five minutes before taking samples. 
Sample Collection Using Tefton Bailer

General Sample Collection Procedure
To reduce the water-flow rate during sample collection, turn the throttie control on the left side of the control pane? in the counterclockwise direction. To increase the flow rate, turn the throttle control clockwise.

To optimize pumping efficiency for a specific well depth, refer to the pump manufacturer's operating instructions.

Unclasp the metal bailer from the winch line and replace it with the Teflon bailer.

Disengage the winch clutch and slowly lower the bailer into the water.

Engage the winch clutch when the bailer strikes the water surface.

Aliow about 30 seconds for the sample tube to fill.

Turn on the electric winch and slowly raise the Teflon bailer to the surface.

Lower and rinse the bailer twice before collecting a sample.

Unscrew the cap of the sample container, being carefut not to touch the lip of the bottle or the inside of the Teflon liner. Avoid touching the mouth of the Tefion bailer.

Unclasp the Teflon bailer.

Pour the water from the bailer into the sample container slowly to prevent trapping any air bubbles. Avojd splashing or agitating the water while the sample container is being filled.

Unscrew the cap from the sample container, being careful not to touch the lip of the bottle or the inside of the Teflon liner. Aiso avoid touching the mouth of the discharge line.

Fill the sample bottie slowiy by placing the outlet tube against the inner side of the sample bottle to prevent trapping any air bubbies. Avoid splashing or agitating the water while the bottie is being filied.

NOTE: For those bottles requiring no headspace, the bottle should be filled completely so that a meniscus forms. Cap the bottle immediately, turn it upside down, tap it a few times and check for air bubbles in the sample. If a bubbie exists, discard the sample and repeat the sampling procedures until an 
Tefion Bailer Cleaning Procedure air-free samiple is obtained. There is an exception to this if the bottie to be filled contains a preservative, in which case only one attempt will be made to obtain an air-free sample.

As each container is filled, attach a sample seal to it and piace it in a cooler or ice chest.

Survey the sample container with a GM instrument. If the count is greater than $200 \mathrm{c} / \mathrm{m}$, record it on the field record form and use Radiation Work Procedure 318-EE-1. Contact the EM Supervisor for instructions concerning where the sample is to be taken.

Turn off the air compressor.

Turn the power switch off and then turn the generator off. Unpiug the power cord.

Complete the chain-of-custody and sample-analys is request forms.

Deliver the sample to the appropriate iaboratory for analysis as soon as possible, following chain-of-custody procedures. If it cannot be delivered to the lab the same day, store the sample in a refrigerator located inside a locked building or within a secured area. The refrigerator must maintain a constant temperature of $4^{\circ} \mathrm{C}\left(39^{\circ} \mathrm{F}\right)$. Leave the cooler to be used when the sampies are delivered.

Wash the inside and the outside of the bailer with a mild mixture of dish soap and water.

Rinse the bailer twice with tap water.

Store the bailer in a sealable piastic bag between uses. 


\subsection{CHAIN-OF-CUSTOOY PROCEDURES}

Introduction

Delivery Procedures
To ensure the integrity of the samples from the time of collection through data reporting, the history of the custody of each sample will be documented according to these procedures. A sample is considered to be under a person's custody if it is in any of the following states: 1) in his physical possession; 2) in his view after he has taken possession; 3) secured by him so that no one can tamper with the sample; or 4) secured by him in an area which is restricted to authorized personnel. Anyone having custody of samples must comply with the procedures described below.

Sample Labels

Fill out and affix gummed paper labels to the sample containers prior to or at the time of sample coliection. The label to be used is shown in Exhibit 13.1. The well number noted on the label identifies the well location where the sample was collected.

\section{Sample Seals}

Attach gumuned paper seals to the samples inmediately upon sample collection, before the samples leave your custody. Attach the seal in such a way that the sample cannot be opened without breaking the seal.

\section{Field Record Form}

Record (in black ink) all pertinent information about each sample collected on a field record form and insert into a logbook. It will be a bound book with consecutive?y numbered pages. An example fieid record form is shown in Exhibit 13.2.

\section{Chain-of-Custody Form}

A chain-of-custody form will accompany ail samples from the time they are collected unti? they are disposed of after analysis and reporting. A single form will be used for as many samples as possible. The form to be used is shown in Exhibit 13.3. Each person who handles the sample and signs the form will return a copy of the form to the company contact whose name appears on the top line.

\section{Sample-Analys is Request Form}

UST requires that a sample-analysis request form accompany all samples delivered to the lab. The form to be used is shown in Exhibit 13.4. The field portion of the form will be completed by the sample collector; the laboratory portion will be completed by laboratory personnel. 
Laboratory Acceptance Procedures

Receiving Department
You will normally deliver samples directly to the laboratory on the day of collection. If they cannot be delivered on the day of collection, you must store them in a refrigerator in a locked building. (No shipping of the sampies will be necessary, due to the lab's proximity to the site.) All samples will be accompanied by a chain-of-custody form and a sample-analysis request form. Deliver samples only to authorized laboratory personnel.

The chain-of-custody does not end at the laboratory door, and therefore the laboratory must ensure the continuity of its record by following these procedures:

Remove the sample cooier from the delivery vehicle and bring it into the receiving area.

Check the sample cooler for any obvious damage.

Sign the chain-of-custody and sample-analysis request forms.

If you transfer custody of the cooler to one or more internediates before it is delivered to the Sample Custodian, the chain-of-custody form must reflect every change of custody.

(sample number) - company code

(list of analyses)

(we 1) number)

(bottle preparation)

SAMPLE SIZE :

LAB :

DATE/TIME:

COLLECTOR:

Exhibit 13.1. Sample Label 


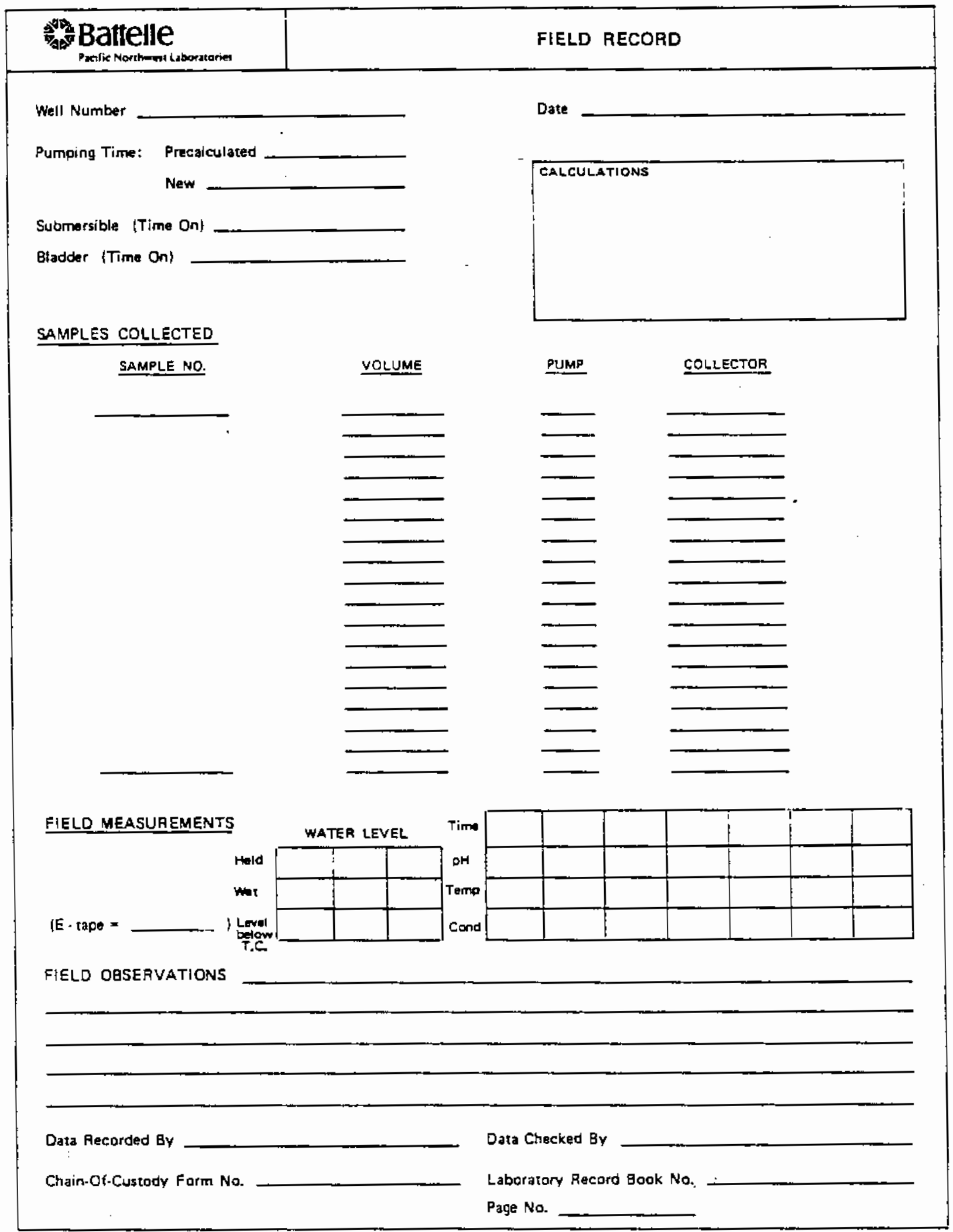

Exhibit 13.2. Field Record Form 


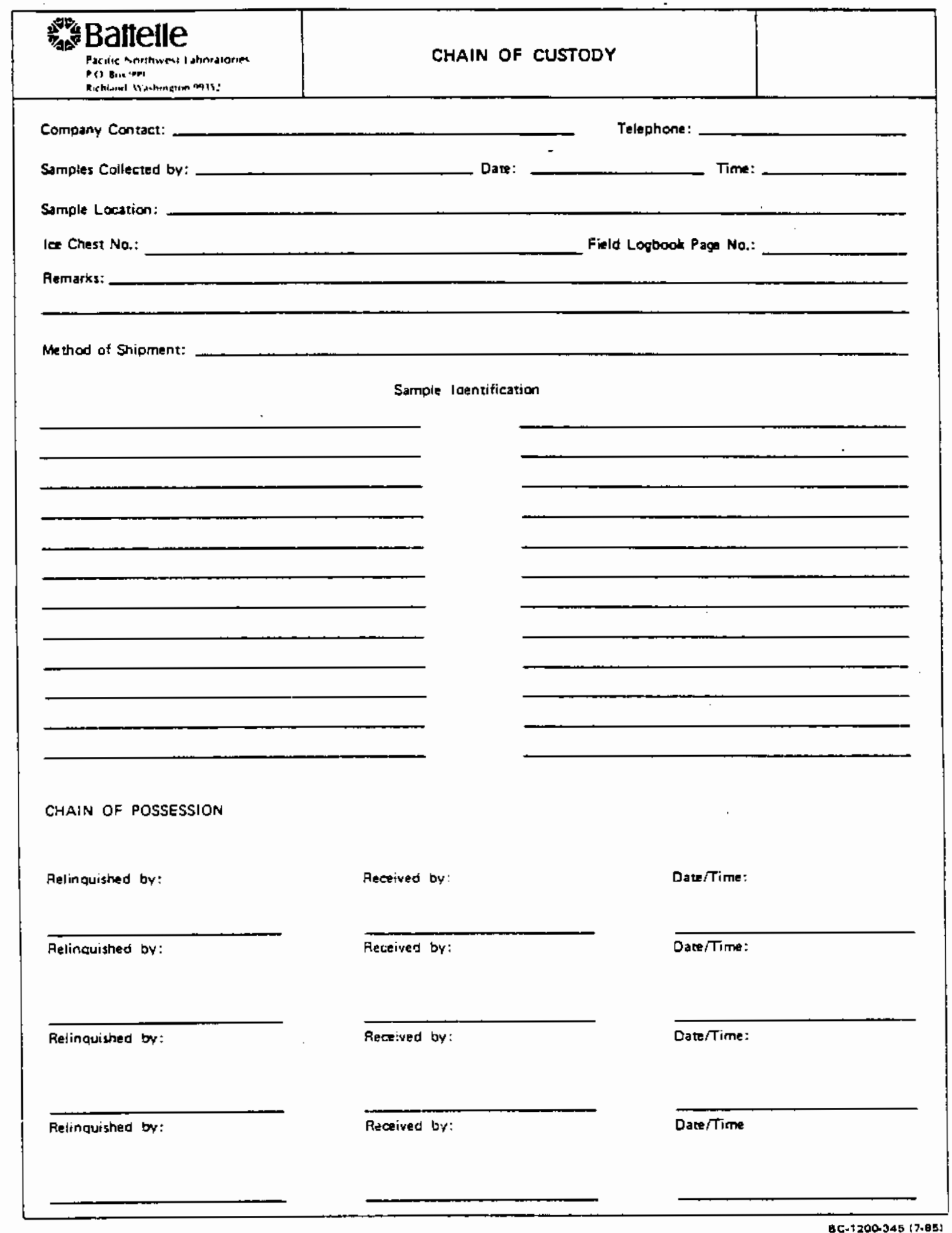

EXHIBIT 13.3. Chain-of-Custody Form

A. 14 
Paciltic Northwest tojorarory

$P \circ 80 x 999$

Richland WA 99352

Colloctor

Dace /Time Sampled

Company Concace
Uniced status Testing Company, inc. 2800 Georg* Wasiningeon Way

Richland WA 9935

CHAIN OF CUSTODY NO
SAMPLE IO
UST SAMPLE ID

COM MENTS

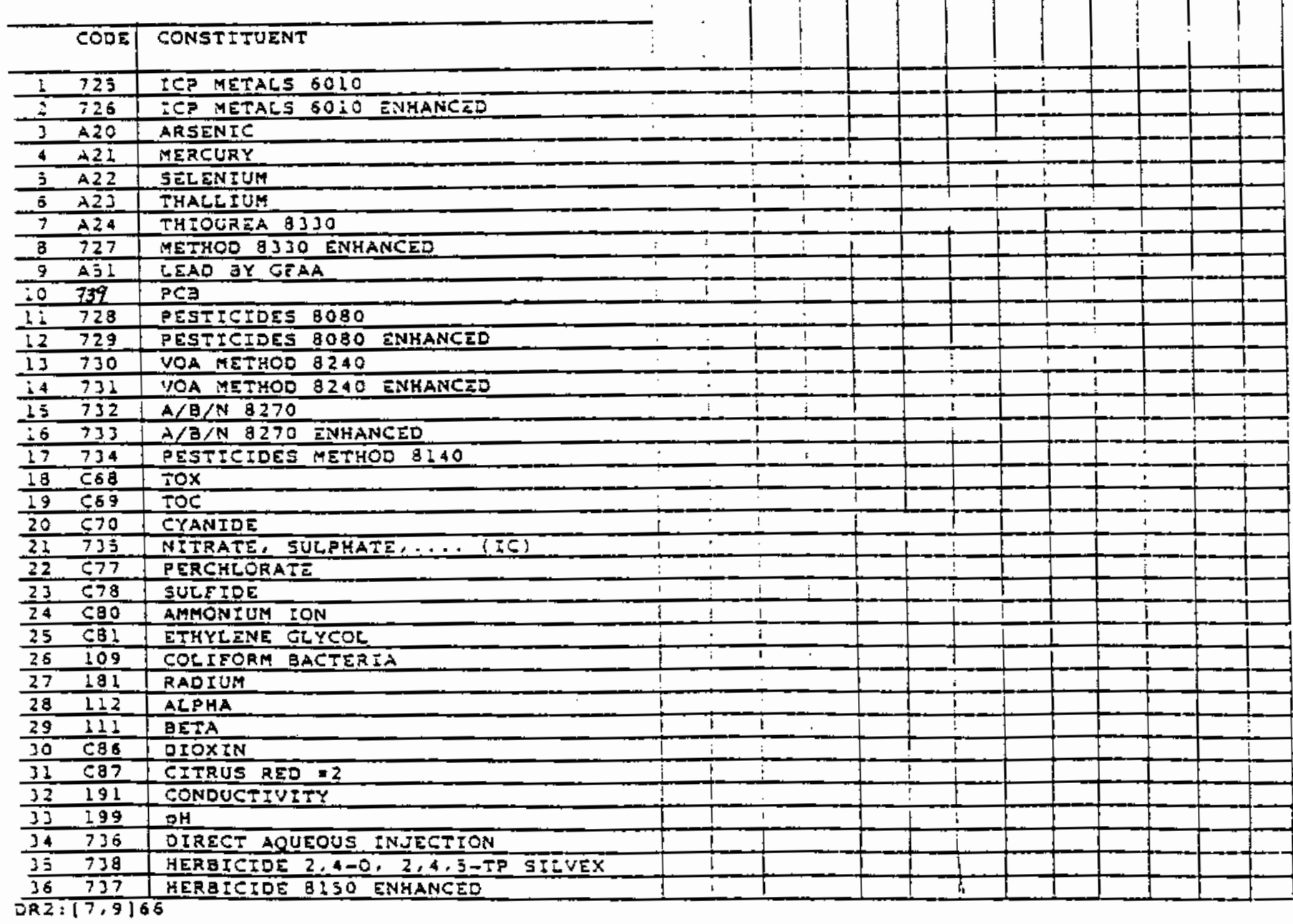

EXHIBIT 13.4. Sample-Analys is Request form 
When the sampie cooler is delivered to you (or your designated alternate), sign the chain-of-custody form.

Then return one copy to the sender and retain the remaining copies. The sample cooler is now your responsibility (or that of your designated alternate). You must now log the samples in.

Examine the sample coolers. On the sample log-in form (Exhibit 13.5), record

- presence/absence of custody seal(s) on the samples

- condition of custody $\operatorname{seat}(s)$.

Open the sample coolers, examine the sample documents, and record on the sample log-in form whether chain-of-custody form(s) are present.

Remove sample containers and record on sample log-in form:

- condition of samples (intact, broken, leaking, etc.)

- presence/absence of sample labels and sample seais

- any discrepancy with chain-of-custody form(s).

If discrepancies are found, contact the sender for clarification.

Once all samples have been properly logged in, send a copy of the sample log-in form to the company contact named on the chain-of-custody form.

Use an internal numbering system for identification of all samples.

Assign internal numbers to the samples and record the numbers on the sample log-in form alongside the corresponding sample number assigned by the collector.

Place the properiy labeled sample containers in the secure storage area. 


\section{SAMPLE}

\section{UST-RD SAMPLE LOG-IN FORM}

DATE :

TIME:

COOLER IO :

CLIENT SAMPLE IO:

UST-RD ID :

NUMBER, OF BOTTLES IN COOLER :

IS CHAIN OF CUSTODY FORM PRESENT? :

CHAIN OF CUSTOOY NUMBER :

IS SAMPLE ANALYSIS REQUEST FORM PRESENT? :

* is the custooy seal on the cooler intact? :

* are the custooy seals on the bottles intact? :

* do the sample labels agree hith the chain of custody sheet? :

- do the sample labels aeree hith the sample analysis REQUEST SHEET? :

* if ansher is 'no', please explain beloh in detail.

SAMPLES LOGGED IN BY:

REVIEHED BY SAMPLE CUSTODIAN:

Govind Rao

Exhibit 13.5. Sample Log-In Form

A. 17 


\subsection{TEMPERATURE MEASUREMENT PROCEDURE}

Introduction

Equipment

Temperature

Measurement

Procedure
Temperature measurements are taken during and after purging of the well, just prior to sample collection. Measurements taken during purging are used to help ensure that the well bore has been sufficiently evacuated, as indicated by stabilization of the temperature. (The $\mathrm{pH}$ and conductivity are measured at the same time for the same reason.) The temperature is considered stable when two consecutive measurements agree within $0.2^{\circ} \mathrm{C}$. The final temperature measurement is taken just prior to sampling and is recorded as an analytical value for the sample. The digital thermometers are regularly checked against a standard thermometer for accuracy.

The following equipment will be needed:

- digital thermometer

- field record forms.

Turn on the digital thermometer. Make sure that the switch is positioned so that the measurements will be in degrees centigrade.

Place the probe into the stream of water being discharged from the pump.

The temperature is indicated by a flashing display, which will normally fluctuate for a few seconds. Wait until fluctuation ceases ( $i . e .$, until the same temperature is indicated on three consecutive flashes), and then record the temperature on the field record form. 


\subsection{CONOUCTIVITY CALIBRATION ANO MEASUREMENT PROCEDURES}

Introduction

Equipment

Conductivity

Calibration

Procedure
Conductivity measurements are taken during and after purging of the well, just prior to sample collection. Measurements taken during purging are used to help ensure that the well bore has been sufficiently evacuated, as indicated by stabilization of the conductivity. (The $\mathrm{pH}$ and temperature are measured at the same time for the same reason.) Conductivity is considered stable when two consecutive measurements agree within 10 umhos. The final conductivity measurement is taken just prior to sampiing and is recorded as an analytical value for the sample. The conductivity meter should be caibrated once a day, before it is taken to the field to begin sampling.

The following equipment will be needed:

- conductivity meter

- distilled or deionized water

- small screwdriver

- standard solution

- field record forms.

Internal Standard

Empty the sample cup on the meter. Rinse it out with distilled or deionized water. Ory the cup thoroughly.

Turn the range switch to TEST.

Press the OPERATE button.

Use the small screwdriver to adjust the CALIBRATE unti? the meter or display reads 8 .

NDTE: This is to be done as a rough calibration or battery check.

Standard Solution

Empty the sample cup. Rinse it out with distilled or deionized water.

Fill the cup with standard solution.

Turn the MODE switch to conductivity.

Turn the RANGE selector switch to the correct range for the standard solution.

Press the DPERATE button. 
Conductivity Measurement

Procedure
Use the small screwdriver to adjust the CALIBRATE until the meter or display reads the solution value.

NOTE: Do not return the conductivity standard solution to the container. Always discard it.

Check that the conductivity meter is properly calibrated by using the internal standard.

Remove the cap from the sample cup.

Rinse the cup with the water to be tested and cump it several times. Then fill the cup with the sample.

Turn the conductivity RANGE switch to the correct range.

Range in umhos

$$
\begin{array}{ll}
\times 1 . & 0-10 \\
\times 10 . & 0=100 \\
\times 100 . & 0=1,000 \\
\times 1,000 . & 0=10,000
\end{array}
$$

Turn the MOOE switch to CONOUCTIVITY.

Press the OPERATE button on the side of the meter.

Read the conductivity on the digital dispiay to the nearest umho and record on field record form. Multiply the meter reading times the scale factor to obtain the correct placement of the decimal point.

After taking the reading, dump the sample and refill the cup with distilled water.

Replace the cap. 


\subsection{PH CALIBRATION AND MEASUREMENT PROCEOURE}

Introduction

Equipment

pH Calibration Procedure
Measurements of the pit are taken during and after purging of the well, just prior to sample collection. Measurements taken during purging are used to help ensure that the well bore has been sufficiently evacuated, as indicated by stabilization of the ph. (Conductivity and temperature are measured at the same time for the same reason.) The $\mathrm{pH}$ is considered stable when two consecutive measurements agree within $0.2 \mathrm{pH}$ units. The final $\mathrm{pH}$ measurement is taken just prior to sampling and is recorded as an analytical value for the sample. The $\mathrm{pH}$ instrument should be calibrated once a day, before it is taken to the field for sampling.

The following equipment will be needed:

- pH meter

- distilled or deionized water

- small screwdriver

- buffer solutions

- field record forms.

Wash the meter's sample cup with distilled water.

Fill the cup with 4.0 buffer solution.

Turn the MOOE switch to $\mathrm{pH}$.

Press the OPERATE button. Use the small screwdriver to adjust the ZERO to make the display read $4.00 \mathrm{pH}$ on the upper meter scale or on the digital display.

Discard the buffer solution. Wash the cup twice with distilled or deionized water.

Fill the cup with 10.00 buffer solution.

Adjust the SLOPE to make the display read $10.00 \mathrm{pti}$.

Rinse the cup again and refill it with $4.0 \mathrm{pH}$ buffer solution. Recheck the $4.0 \mathrm{pH}$ value and adjust the ZERO if necessary.

Single Buffer Calibration.

After the SLOPE is calibrated the first time each day, it may be left alone for subsequent calibration. Recheck the slope as desired. 
pH Measurement

Procedure
Cajibrate with a buffer solution that is close to the range of interest. If the process $\mathrm{pH}$ is from 6.0 to 9.0 , use a 7.0 buffer solution for single-point calibration.

With the buffer solution in the cup, recalibrate only the STO to make the display read the desired value.

NOTE: Do not return buffer solutions to their contajners. Always discard them.

Ensure that the $\mathrm{pH}$ instrument is properly calibrated.

Remove the cap from the sample cup.

Rinse the cup with the water to be tested several times.

Then fill the cup with the sample.

Turn the MOOE selector switch to $\mathrm{pH}$.

Press the OPERATE button on the side of the meter.

Read the $\mathrm{pH}$ on the upper meter scale or on the digital display to the nearest tenth of a unit. Record the value on the field record form.

Oump the sample and refill the cup with distilled water. Replace the cap. 
APPENDIX B

DATA EVALUATION 
APPENDIX B

DATA EVALUATION

This appendix presents the methods by which the annual determination of flow rate and direction will be made in the unconfined aquifer under the Solid Waste Landfill, and the statistical procedure for determining if a significant change over background level has occurred.

ANNUAL DETERMINATION OF FLOW RATE AND DIRECTION

The depth-to-water measurements will be used to determine the flow rate and direction in the uppermost aquifer. These measurements will be used to produce water-table maps and thereby determine the hydraulic gradient and the flow direction. This information, together with Darcy's Law, witl be used to determine the flow rate. The regulations require that this determination be made at Teast annually.

\section{STATISTICAL PROCEDURE FOR DETERMINING SIGNIFICANT CHANGE}

WAC 173-304-490 (2) (f) requires that "the owner or operator shall use a statistical procedure for determining whether a significant change over background has occurred." However, no specific statistical procedure is given, nor is any definition of "significant change," nor are any criteria for Type I and Type II errors suggested. Without these design criteria, it is impossible to develop a particular statistical procedure that meets specific requirements. Even if such design criteria were specified in the regulations, it is impossible to efficiently design an appropriate statistical procedure without an understanding of the probability distribution that describes the data and a stable and reliable measure of the quantities that will be used as the criteria for determining "significant changes," that is, the inherent variability in the data for the Solid waste Landfill.

Because of these factors, the following approach will be taken. As the quarteriy data are received, they will be reviewed by a qualified statistician who will then use the information gathered from the Solid Waste Landfill for 
the first 4 quarters to design the most appropriate statistical procedures to be used. These suggested statistical procedures will then be submitted to the jurisdictional health department for their approval with the guidance of the State Department of Ecology.

Although the exact form of the statistical procedures is not known at this time, philosophies and methods described in Ground-Water Monitoring Plans and Statistical Procedures to Detect Leaking at Hazardous Waste Facilities (PNL 1986) will be used as guidance when developing these procedures.

\section{REFERENCES}

Pacific Northwest Laboratory (PNL). 1986. Ground-Water Monitoring Plans and Statistical Procedures to Detect Leaking at Hazardous Waste Facilities. PNL5754, Pacific Northwest Laboratory, Richland, Washington. 
APPENDIX $C$

STATE REGULATIONS 


\section{APPENDIX C}

\section{STATE REGULATIONS}

This appendix contains the section, WAC 173-304-490, that gives the specific requirements for ground-water monitoring of a soljd waste landfill. This section is part of the 1985 WAC Supplement, Chapter 173-304 WAC, Minimum Functional Standards for Solid Waste Handling. 
WAC 173-304-490 Ground water monitoring requirements. (1) Applicability. These requirements apply to owners and operators of landfills, piles, landspreading disposal facilities, and surface impoundments that are required to perform ground water monitoring under WAC 173-304-400.

(2) Ground water monitoring requirement5.

(a) The ground water monitoring system must consist of at least one background or upgradient well and three down gradient welis, installed at appropriate locations and depths to yicld ground water samples from the upper most aquifer and all hydraulically connected aquiers betow the active portion of the facilizy.

(i) Represent the quality of background water that has not been affected by leakage from the active area: and

(ii) Represent the quality of ground water passing the point of compliance. Additional wells may be required by the jurisdictional health department in complicated hydrogeological settings or to define the extent of contamination detected.

(b) All monitoring wells must be cased in a manner that maintains the integrity of the monitoring well bore hole. This casing must allow collection of representative ground water samples. Wells must be constructed in such a manner as to prevent contamination of the samples, the sampled strata. and between aquifers and water bearing strata and in accordance with chapter 173-160 WAC. Minimum standards for construction and maintenance of water wells.

(c) The ground water monitoring program must include at a minimum, procedures and techniques for:

(i) Decontamination of drilling and sampling equipment;

(ii) Sample collection;

(iii) Sample preservation and shipment;

(iv) Analytical procedures and quality assurance:

(v) Chain of custody control; and

(vi) Procedures to ensure employee health and safety during well installation and monitoring.

(d) Sample constituents.

(i) All facilities shall test for the following perameters:

(A) Temperature;

(B) Conductivity;

(C) $\mathrm{pH}$ :

(D) Chloride;

(E) Nitrate, nitrite, and ammonia as nitrogen;

(F) Sulfate;

(G) Dissolved iron:

(H) Dissolved zinc and manganese:

(l) Chemical oxygen demand;

(J) Total organic carbon; and

(K) Total coliform.

(ii) The jurisdictional health department in consultation with the department may specify additional or fewer constituents depending upon the nature of the waste; and - (iii) Test methods used to detect the parameters of (d)(i) of this subsection shall be EPA Publication Number SW-346. Test Methods for Evaluating Solid Wiste - Physical/Chemical Methods except for total coliform C.2 which shail use the latest edition of Standard Methods for the Examination of $W_{\text {ater }}$ and Wastewater.

(e) The ground water monitoring program must include a determination of the ground water surface elevation each time ground water is sampied. (f) The owner or operator shall use a statistical procedure for determining whether a significant change over background has occurred. The jurisdictional health department will approve such a procedure with the guidance of the department.

(g) The owner or operator must determine ground water quality at each montoring well at the compliance point at least quarterly during the life of an active area (including the closure pertod) and the posiclosure care period. The owner or operator must express the ground

water quality at each monitoring well in a form necessary for the determination of statistically significant increases.

(h) The owner or operator must determine and report the ground water flow rate and direction in the uppermost aquifer at least annually.

(i) If the owner or operator determines that there is a statistically significant increase for parameters or constituents at any monitoring well at the compliance point, the owner or operator must:

(i) Notify the jurisdictiona! health department of this finding in writing within seven days of receipt of the sampling data. The noti $\sqrt{1}$ cation must indicate what pa. rameters or constituents have shown statistically significant increases;

(ii) Immediately resample the ground water in all monitoring wells and determine the concentration of all constituents listed in the definition of contamination in WAC 173-304-100 including additional constituents identified in the permit and whether there is a statistically significant increase such that the ground water performance standard has been exceeded, and notify the jurisdictional health department within fourteen days of receipt of the sampling data.

(j) The jurisdictional health department may require corrective action programs including facility closure if the performance standard of WAC $173-304-460$ (2)(a) is exceeded and, in addition, may revoke any permit and require reapplication under WAC 173-304600.

(3) Corrective action program. An owner or operator required to establish a corrective action program under this section must, at a minimum with the approval of the jurisdictional health officer:

(a) Implement a corrective action program that re. duces contamination and if possible prevents constituents from exceeding their respective concentration limits at the compliance point by removing the constituents. treating them in place. or other remedial measures:

(b) Begin corrective action according to a written schedule after the ground water performance standard is exceeded;

(c) Terminate corrective action measures once the concentrations of constituents are reduced to levels below the limits under WAC 173-304-460 (2)(a). [Statutory Authority: Chapter 43.21A RCW. 85-22-013 (Order 85-18), \$ 173-304-490, riled 10/28/85.] 
PNL-6930

UC $-11,41$

DISTRIBUTION

No. of

Copies

OFFSITE

2 DOE/Office of Scientific and Technical Information

ONSITE

3 Pacific Northwest Laboratory

Technical Report Files (3)

Distr.1 


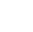

$\because$ 